\title{
Long-term trends observed in the middle atmosphere temperatures using ground based LIDARs and satellite borne measurements
}

\author{
P. Kishore ${ }^{1}$, M. Venkat Ratnam ${ }^{2}$, I. Velicogna ${ }^{1}$, V. Sivakumar ${ }^{3}$, H. Bencherif ${ }^{4}$, B. R. Clemesha ${ }^{5}$, D. M. Simonich ${ }^{5}$, \\ P. P. Batista ${ }^{5}$, and G. Beig ${ }^{6}$ \\ ${ }^{1}$ Department of Earth System Science, University of California, Irvine, CA, 92697, USA \\ ${ }^{2}$ National Atmospheric Research Laboratory (NARL), Department of Space, Gadanki, India \\ ${ }^{3}$ School of Chemistry and Physics, University of KwaZulu Natal, Durban, South Africa \\ ${ }^{4}$ Laboratoire de l'Atmosphère et des Cyclones, Université de la Réunion, Reunion Island, France \\ ${ }^{5}$ Instituto Nacional de Pesquisas Espaciais, São José dos Campos/SP, Brazil \\ ${ }^{6}$ Indian Institute of Tropical Meteorology, Pune, India \\ Correspondence to: P. Kishore (kishore@uci.edu)
}

Received: 11 October 2013 - Revised: 10 February 2014 - Accepted: 11 February 2014 - Published: 31 March 2014

\begin{abstract}
Long-term data available from Lidar systems located at three different locations namely São José dos Campos, Brazil $\left(23.2^{\circ} \mathrm{S}, 45.8^{\circ} \mathrm{W}\right)$, Gadanki $\left(13.5^{\circ} \mathrm{N}, 79.2^{\circ} \mathrm{E}\right)$ and Reunion $\left(20.8^{\circ} \mathrm{S}, 55.5^{\circ} \mathrm{E}\right)$ have been used to investigate the long-term variations like Annual, Semi-annual, Quasi-biennial, El Nino Southern Oscillation and solar cycle. These oscillations are also extracted from simultaneous satellite borne measurements of HALogen Occultation Experiment (HALOE) instrument onboard UARS and SABER onboard TIMED over these stations making largest time series covering the entire middle atmosphere. A good agreement is found between the LIDAR and satellite-derived amplitudes and phases between 30 and $65 \mathrm{~km}$ altitude, which suggests that satellite measurements can be used to investigate the long-term trends globally. Latter measurements are extended to $80 \mathrm{~km}$ in order to further investigate these oscillations. Large difference in the amplitudes between the eastern pacific and western pacific is noticed in these oscillations. Changing from cooling trends in the stratosphere to warming trends in the mesosphere occurs more or less at altitude around $70 \mathrm{~km}$ altitude and this result agrees well with that observed by satellite measurements reported in the literature. The peak in the cooling trend does not occur at a fixed altitude in the stratosphere however maximum warming trend is observed around $75 \mathrm{~km}$ at all the stations. The observed long-term trends including various oscillations are compared with that reported with various techniques.
\end{abstract}

Keywords. Meteorology and atmospheric dynamics (middle atmosphere dynamics)

\section{Introduction}

In recent days, climate change is posing unprecedented serious challenges that society has ever faced. There is now an overwhelming consensus that human activities have been affecting the composition of Earth's atmosphere. The scientific facts are clear - recognised by the Nobel Prize in 2007 that phase of climate change is accelerating and it is endangering our safety and economic development. Over the last three to four decades significant progress has been made in observing, understanding and to some extent predicting the variability and changes in Earth's climate system. Impressive progress in climate science, reflected notably in the recent assessment report of the Intergovernmental Panel on Climate Change (IPCC, 2007) provided robust findings on the cause of climate change and its impacts over the next decades.

Perturbations in the atmosphere caused by various human activities are not only confined to the lower atmosphere but also extend into middle and upper atmosphere (Beig et al., 2003, 2011a). In view of this, it has become more important and vital to study the variations due to natural activities in parameters affecting climate and to distinguish them from perturbations induced by global change in all layers of the atmosphere. As the amplitude of temperature variations increases 
with respect to altitude due to the decrease in density, the effects of climate change are likely to be more pronounced at higher altitudes. In this study, we concentrate on the effects of climate change in the tropical middle atmosphere.

Global-mean cooling of the stratosphere is widely viewed as evidence for a discernible anthropogenic impact on the climate system (e.g., WMO, 1999; Ramaswamy et al., 2001; Shine et al., 2003; Beig et al., 2003). Assessments of globalmean stratospheric temperatures based on NOAA satellite measurements since 1979 have revealed that temperature below $35 \mathrm{~km}$ has dropped by $\sim 0.75 \mathrm{~K} \mathrm{decade}^{-1}$, and the temperature near $50 \mathrm{~km}$ has dropped by $\sim 2.5 \mathrm{~K} \mathrm{decade}^{-1}$ (Ramaswamy et al., 2001). Temperature trends derived from radiosonde data show stronger stratospheric cooling trends as compared to satellite measurements (Seidel et al., 2001; Lanzante et al., 2003a, b; Randel and Wu, 2006). By combining satellite, radiosonde and LIDAR observations Randel et al. (2009) reported cooling trend of $\sim 0.5 \mathrm{~K} \mathrm{decade}^{-1}$ in the lower stratosphere over much of the globe during the period 1979-2007.

Temperature variability associated with the 11-year solar cycle, El Niño-Southern Oscillation (ENSO), and the QuasiBiennial Oscillation (QBO) has been found to be prominent in the lower and middle atmosphere, and plays a key role in the overall balance of its composition and circulation (Reid, 1994). The QBO is one of several possible "external" influences on the inter-annual variability of the northern stratospheric flow. Other possible forcings include the solar cycle (probably strongest in the equatorial upper stratosphere associated with ozone heating), the remote effects of ENSO, and forcing from below by tropospheric circulation anomalies (Baldwin and O'Sullivan, 1994). Recently Li et al. (2008) reported inter-annual variability between 15 and $85 \mathrm{~km}$ associated with the 11-year solar cycle, ENSO, and the QBO using Hawaii LIDAR temperature measurements from 1994 to 2007. They revealed the dominance of the QBO (1-3 K) in the stratosphere and mesosphere, stronger winter signatures of ENSO in the troposphere and lower stratosphere $(\sim 1.5 \mathrm{~K} / \mathrm{MEI})$, and maxima of solar cycle $\sim 1.3 \mathrm{~K} / 100 \mathrm{~F} 10.7$ units at 35 and $55 \mathrm{~km}$. A number of studies on the solar cycle influence on the temperature data have been carried out and reported (Clemesha et al., 1997; Sridharan et al., 2009; Keckhut et al., 2005; Remsberg and Deaver, 2005; Fadnavis and Beig, 2006; Remsberg, 2008; Beig, 2011b; Fadnavis et al., 2012). In addition, Li et al. (2011) studied the long-term trend and solar cycle in the stratosphere and mesosphere using the long-term Rayleigh lidar temperature dataset at three different sites in the Northern Hemisphere. The significant cooling stratosphere and mesosphere temperature trends were found over two middle latitude sites.

In this paper, dominant oscillations such as semi-annual oscillation (SAO), annual oscillation (AO), Quasi-biennial (QBO), El Niño-Southern Oscillation (ENSO) and the solar cycle along with long-term trends obtained using datasets from three LIDAR stations which two are located in the
Southern Hemisphere and one in Northern Hemisphere within the tropical latitudes. Simultaneous satellite measurements by combining HALogen Occultation Experiment (HALOE) aboard the Upper Atmosphere Research Satellite (UARS) and from the Sounding of the Atmosphere using Broadband Emission Radiometry (SABER) instrument aboard the Thermosphere-Ionosphere-Mesosphere Energetics and Dynamics (TIMED) satellite are also used to compare how these oscillations are reflected in these measurements. Latter measurements are extended to complete middle atmosphere to investigate the long-term trends.

\section{Database}

\subsection{LIDAR measurements}

Long-term data available from Rayleigh LIDARs located one at tropical latitude (Gadanki $\left(13.5^{\circ} \mathrm{N}, 79.2^{\circ} \mathrm{E}\right)$ ) and two at sub-tropical latitudes (Reunion $\left(20.8^{\circ} \mathrm{S}, 55.5^{\circ} \mathrm{E}\right)$ and São José dos Campos, Brazil $\left.\left(23.2^{\circ} \mathrm{S}, 45.8^{\circ} \mathrm{W}\right)\right)$ are used. Locations of these three stations are shown in Fig. 1. We have used the data from the Reunion and São José dos Campos LIDAR systems for the period 1994 to 2007 and from Gadanki for the period 1998 to 2011. In general, there exist 8-15 measurements in each month regardless of the season during the above mentioned periods. Detailed description of this LIDAR system is given in Keckhut et al. (2004). Another LIDAR has been operated in Sao Jose dos Campos, Brazil since 1972 and is mainly dedicated to the study of mesospheric sodium at the $589 \mathrm{~nm}$ resonant line in the $80-105 \mathrm{~km}$ altitude range (Batista et al., 2008). The laser capability improved in the beginning of 1993, which enabled the Rayleigh signal retrieved from $\sim 35$ to $\sim 65 \mathrm{~km}$. The third LIDAR system is located at Gadanki and has been in operation since 1998. Detailed description of Gadanki LIDAR system is provided in Ratnam et al. (2002), Sivakumar et al. (2003), Kishorekumar et al. (2008). Note that trends are estimated from Gadanki LIDAR measurements are already presented by Sridharan et al. (2009); however, in this report we have extended with four more years covering more than a solar cycle and also from two more locations. These long-term trends are further extracted with the satellite measurements and checked the consistency between the two.

Temperature profiles from the Rayleigh LIDAR are estimated following the analytical method given by Chanin and Hauchecrone (1984). In the altitude range, where the contribution from Mie scattering is negligible $(35-80 \mathrm{~km})$, the recorded signal intensity, after applying the corrections for the range and atmospheric transmission, is proportional to the molecular number density. The constant of proportionality is evaluated and density profile derived using the number density taken from an appropriate model (CIRA-86) for the altitude of $80 \mathrm{~km}$, where the signal-to-noise ratio is fairly high (Rees et al., 1990; Barnett and Corney, 1985). 


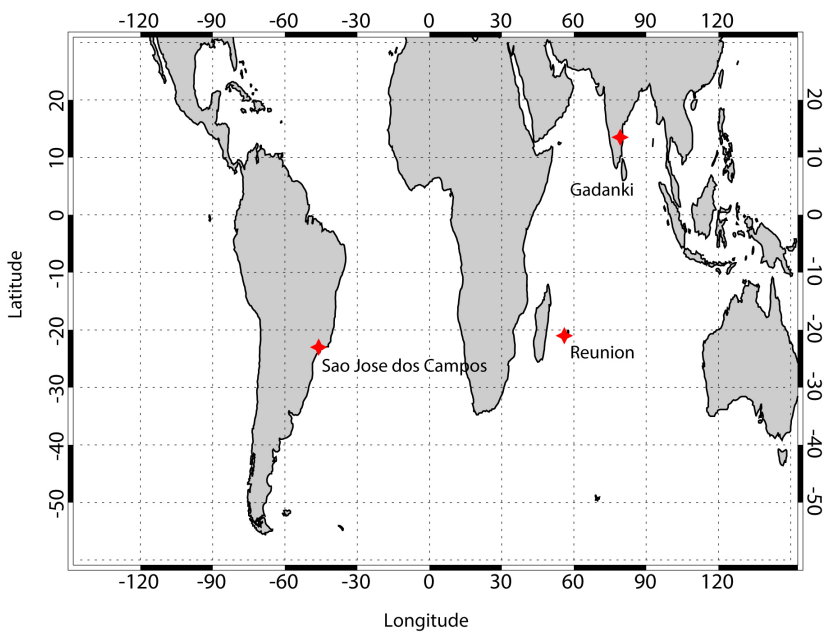

Fig. 1. Map showing the locations of the three stations (São José dos Campos, Reunion, and Gadanki) where long-term Lidar data observations were made available.

The pressure profile is computed using the pressure at the top of the atmospheric model, and the measured density profile assuming the atmosphere to be in hydrostatic equilibrium. Adopting the perfect gas law, the temperature profile is computed using the derived density and pressure profiles. Any uncertainty in the pressure at the top of the profile would contribute to temperature uncertainty; however, the uncertainty falls rapidly with decreasing altitude. For $15 \%$ uncertainty in the pressure at the top of the altitude range, the temperature uncertainty would be $<2 \%$ at $15 \mathrm{~km}$ below the top (Leblanc et al., 1998). In individual profiles, the temperature measurement accuracy varies between $0.5-1.5 \mathrm{~K}$ in the stratosphere and $2-3 \mathrm{~K}$ in mesosphere. We have used the nighttime averaged profiles, which correspond to at least $2 \mathrm{~h}$ of measurement, and thereby provide a good signal-to-noise ratio (SNR) and better accuracy. Though reasonably good data is available up to $70 \mathrm{~km}$ altitude, for the present study we used the data up to $60 \mathrm{~km}$ only.

\subsection{Satellite measurements}

\subsubsection{HALOE onboard UARS satellite}

The HALOE instrument on the UARS satellite (Russell et al., 1993) views solar infrared radiation in the 2.5 to $10 \mu \mathrm{m}$ regimes by means of solar occultation and measures water vapour, ozone, methane, temperature and aerosols. Over the course of a year, observational coverage extends from $80^{\circ} \mathrm{S}$ to $80^{\circ} \mathrm{N}$; however, the majority of orbits do not extend south of $45^{\circ} \mathrm{S}$ or north of $45^{\circ} \mathrm{N}$. The $57^{\circ}$ inclination angle of UARS results in an occultation sampling geometry that tends to cause measurements to dwell at high latitudes, and then sweep rather rapidly through the mid-latitude/tropics to the opposite hemisphere. This results in high latitudes having a large number of profiles for some seasons, fol- lowed by very few profiles for other seasons. Atmospheric aerosol concentrations above $35 \mathrm{~km}$ are assumed to be negligible in order to retrieve the temperature profile. It provides day and night temperature profiles in the altitude range from $\sim 35 \mathrm{~km}$ to $80 \mathrm{~km}$ (Hervig et al., 1996; Remsberg et al., 2002). We utilised the temperature profiles available from 1994 to 2005 . A detailed discussion related to the validation of HALOE data can be found in the literature (Russell et al., 1993; Singh et al., 1996; Remsberg et al., 2002). Hervig et al. (1996) validated the HALOE temperatures with LIDAR and rocket measurements and they found typically have random differences of $\sim 5 \mathrm{~K}$ for altitudes below $65 \mathrm{~km}$. An intercomparison study by Randel et al. (2004) based on different kinds of middle atmosphere temperature measurements also confirmed that the LIDAR and HALOE are differing within $\pm 5 \mathrm{~K}$. These findings are supported further in more recent results by Sivakumar et al. (2011), that the observed temperature differences between LIDAR and HALOE observations are found to be within $\pm 6 \mathrm{~K}$.

\subsubsection{SABER onboard TIMED satellite}

In addition to the data from LIDARs and HALOE we have also utilised temperature data obtained from the SABER instrument onboard the TIMED satellite. The TIMED satellite is at an altitude of $625 \mathrm{~km}$ with an orbital inclination of about $74.1^{\circ}$ from the equator and its orbital period of approximately $97 \mathrm{~min}$. SABER measures global temperature at high vertical resolution from the lower stratosphere to the lower thermosphere. The observation latitude range is from $53^{\circ}$ in one hemisphere to $83^{\circ}$ in the other, and the orientation of latitude coverage flips to the opposite hemisphere approximately every 60-days. The objective of the TIMED mission is to develop climatologies of key atmospheric parameters in the altitude regions ranging from the tropopause to the F-region (Remsberg et al., 2003; Mertens et al., 2004). Mertens et al. (2001) calculated the uncertainty of temperature retrieval which is in the order of $1-3 \mathrm{~K}$ in the lower stratosphere, $\sim 1 \mathrm{~K}$ near the stratopause, and $\sim 2 \mathrm{~K}$ in mesosphere and lower thermosphere. We have used SABER version 1.07 datasets during the period from 2002 to 2011.

\section{Analysis procedure}

The nightly-mean temperature profiles from the LIDAR systems are averaged over a month for each station. Since the LIDAR (São José dos Campos, Reunion and Gadanki) and satellites (HALOE and SABER) datasets have different vertical resolutions, each individual monthly profile has been interpolated to one kilometre spacing in order to make the data analysis and the comparisons between the instruments easier. Later quality checks are applied to check the consistency and continuity of the data. For dataset consistency purpose, we applied a consensus-averaging technique to derive 
the monthly-means, which is outlier resistant (Narayana Rao et al., 1998). In general, the time-series of temperature profiles are dominated by natural periodic signals. The monthlymean temperature data is used for extracting components of SAO, AO, QBO, ENSO and the solar cycle. The effects of the mentioned natural periodic signals are removed in order to extract the long-term trends. At each altitude, we applied regression analysis to the time series, which can be expressed as the following equation (Randel and Cobb, 1994).

$$
\begin{aligned}
T(t, z) & =\alpha(z)+\beta(z) t+\gamma(z) \mathrm{QBO}(t)+\delta(z) \operatorname{Solar}(t) \\
& +\varepsilon(z) \operatorname{ENSO}(t)+\operatorname{resid}(t) .
\end{aligned}
$$

The coefficients, $\alpha, \beta, \gamma, \delta$, and $\varepsilon$ are determined in leastsquares sense at each altitude $(z)$ using the following expressions.

$\alpha(z)=A_{0}+\sum_{i=1}^{3}\left[A_{i} \times \cos \omega_{i} t+A_{i+1} \times \sin \omega_{i} t\right]$,

where $\omega_{i}=2 \pi i / 12$.

As a QBO proxy (QBO $(t))$, we have used Singapore monthly-mean QBO zonal winds $\left(\mathrm{m} \mathrm{s}^{-1}\right)$ at $30 \mathrm{hPa}$. We used the Ottawa monthly-mean F10.7 solar radio flux indices as solar proxy (solar $(t))$. As a proxy for the effects of El NiñoSouthern Oscillation (ENSO $(t)$ ), we use the Southern Oscillation Index (SOI), which calculated from monthly-mean sea-level pressure (MSLP) at Tahiti $\left(18^{\circ} \mathrm{S}, 150^{\circ} \mathrm{W}\right)$ minus MSLP at Darwin $\left(13^{\circ} \mathrm{S}, 131^{\circ} \mathrm{E}\right)$. The long-term time series of the QBO zonal winds, F10.7 cm solar flux, and Southern Oscillation Index (SOI) are publicly available at http: //www.esrl.gov/psd/data/climateindices/list/. For error estimates for each oscillation, we followed the technique outlined in Neter et al. (1985), and obtained regression coefficients from the least-squares analysis (Randel and Cobb, 1994).

For the satellite measurements, we selected the overpasses that are within $5^{\circ}$ latitude and $10^{\circ}$ longitude separation from a given LIDAR location. All satellite-derived profiles are averaged to calculate daily mean-profiles at a given location, and the monthly-mean temperature profiles are estimated using daily-mean profiles. Missing data is linearly interpolated to fill the gap as was done for LIDAR measurements. For regression analysis purposes, we merged the data from HALOE available over 1994 to 2002, and the data from SABER available over 2003 to 2011 . To prevent the effects of inter-mission biases, we checked the consistency of the two different satellite measurements before merging the datasets. The processes mentioned above are also applied to the satellite measurements to extract the various oscillations and the long-term trends.

\section{Results and discussion}

\subsection{Monthly mean temperature structure}

Figure 2a-c show the composite monthly-mean temperature over the altitude region of 30-65 km derived from LIDARs located at São José dos Campos, Reunion and Gadanki, respectively. Note that data has been averaged over the period of 1994-2005 for the São José dos Campos and Reunion locations and over 1998-2005 for the Gadanki location. In general, more or less similar behavior in the temperatures is found among the stations. The stratopause is located between 45 and $50 \mathrm{~km}$ at all the stations and though it is not clearly observed from the figure, the effects of semi-annual oscillations (SAO) are noticed (Kishorekumar et al., 2008). The SAOs correspond to the oscillations at the stratopause SAO (Nee et al., 2002). Figure 2 also reveals clear temperature variations with peak temperatures lying in the range of 264-266 K during February-April and September-October around stratopause altitudes $(\sim 45-50 \mathrm{~km})$. The observed Reunion temperatures are 2-3 K warmer than Gadanki and São José dos Campos in the month of December. At altitudes below $40 \mathrm{~km}$ and above $55 \mathrm{~km}$, the temperature is nearly steady with no apparent seasonal variation.

As one of the aims is to check the consistency in the satellite measurements, the daily mean difference is estimated using the coincidence profiles from satellite data and the composite monthly mean temperature difference between the LIDARs and HALOE measurements over the altitude region of $30-65 \mathrm{~km}$ are shown in Fig. $2 \mathrm{~d}-\mathrm{f}$ and corresponding standard deviations are shown in Fig. $2 \mathrm{~g}-\mathrm{i}$. The differences and standard deviations between LIDAR and HALOE are low below $40 \mathrm{~km}$ and can reach as high as $5 \mathrm{~K}$ between 50 and $60 \mathrm{~km}$ in the case of São José dos Campos. The differences are larger over the Reunion location ranging up to $7 \mathrm{~K}$ between $55 \mathrm{~km}$ and $60 \mathrm{~km}$ during the southern (Austral) winter period (JuneAugust). Interestingly, the differences are minima over the Gadanki location compared to other two stations lying within $3 \mathrm{~K}$. Another interesting observation is the positive difference between Gadanki LIDAR and HALOE measurements during the months of the Indian Summer Monsoon (June to September). These differences might be due to the increased cloud cover and atmospheric moisture during the monsoon season affecting the LIDAR-derived temperature and reducing the measurement accuracy.

The stratospheric temperature difference between measurement techniques may be due to several reasons including LIDAR temperature analysis algorithms, latitudinal variations, and differences in sampling of the geophysical temperature field by each remote-sensing technique. It should be remembered that the HALOE profiles are limb obtained on dusk and dawn and Lidar observations are vertical averages of two or more hours during night times. In addition, the effects of planetary and gravity waves can lead to biases in any comparisons that do not have similar spatial averaging scales 

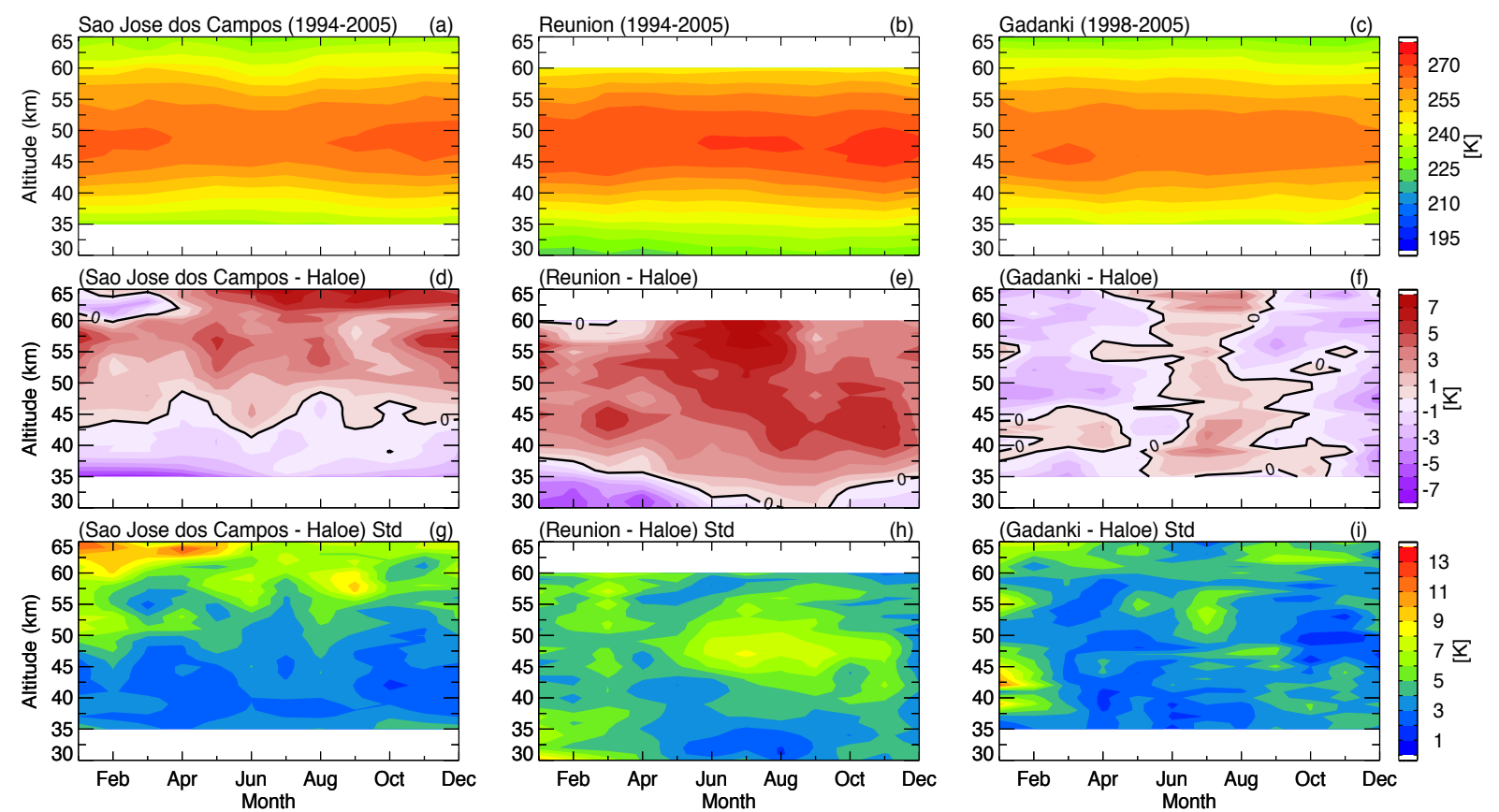

Fig. 2. Monthly mean temperature observed over (a) São José dos Campos, (b) Reunion, and (c) Gadanki averaged during 1994-2005, 19942005, and 1998-2005, respectively. Monthly mean temperature difference and standard deviations observed between HALOE and respective lidars are shown in (d)-(f) and (g)-(i), respectively.

for their measurements (Keckhut et al., 1996). Standard deviations are higher, wherever the temperature differences are greater. Below $45 \mathrm{~km}$ the standard deviations are about $2 \mathrm{~K}$, and it increases with altitude as the density decreases. The standard deviations are high $(4-6 \mathrm{~K})$ above $55 \mathrm{~km}$. While there is no systematic seasonal dependence, the largest standard deviations are found at the São José dos Campos location during January-March above $62 \mathrm{~km}$ altitude and range between 8 and $10 \mathrm{~K}$. The apparent seasonal variability may be due to the planetary wave propagation in the winter middle atmosphere.

The most recent study of Sivakumar et al. (2011) indicates very good agreement between the Reunion LIDAR and HALOE seasonal observations with maximum deviation in the order of $\sim 6 \mathrm{~K}$ between 35 and $60 \mathrm{~km}$ altitude region. The seasonal characteristics of stratopause are found to be consistent with earlier studies using LIDAR, rocket and satellite data (Mohankumar, 1994; Parameswaran et al., 2000; Kishorekumar et al., 2008). Though good agreement between the monthly temperatures from three LIDARs and HALOE measurements are found there are a few notable differences. We consider such differences are acceptable due to different observational times, sampling volumes (including latitudinal/longitudinal discrepancies in selecting HALOE profiles) and vertical resolutions (Sivakumar et al., 2003; Kishorekumar et al., 2008). The differences between LIDAR and HALOE temperatures may also be related to the facts that LIDAR datasets have the spatial and temporal sampling constraints, and HALOE datasets may suffers from tidal effects due to orbital drift (Funatsu et al., 2008; Raju et al., 2010). In addition, deviations in temporal coincidence are a particularly difficult issue for comparisons with solar occultation measurements (Remsberg et al., 2002). From Fig. 2, we observed that LIDAR-derived temperatures are colder than the HALOE-derived temperatures below $35 \mathrm{~km}$, specifically at the São José dos Campos and Reunion stations. This may be due to the errors in LIDAR-derived temperatures in the lower part of the profile $(30-35 \mathrm{~km})$ from the presence of aerosols, nonlinearity of the detector, and misalignment effects (Beig et al., 2003). In the upper part (above $60 \mathrm{~km}$ ), the errors are mainly due to uncertainties in the reference pressure needed to initialise the analysis and photon noise (Keckhut et al., 1996).

In order to use/merge HALOE and SABER measurements to see the long-term trends, we compare the measurements during the overlapping years at the three LIDAR locations. To understand the geographical variances, only HALOE and SABER profiles centred within $\pm 5^{\circ}$ latitude and $\pm 10^{\circ}$ longitude separation over each LIDAR location is considered. In addition, HALOE and SABER monthly-averages are considered only for the available days of LIDAR observations. The monthly-mean differences and corresponding standard deviations are shown in Fig. 3. As evident from these figures, the HALOE-derived temperatures exhibit reasonable agreements with the SABER temperature measurements over the three locations. However, the HALOE mean temperatures are 

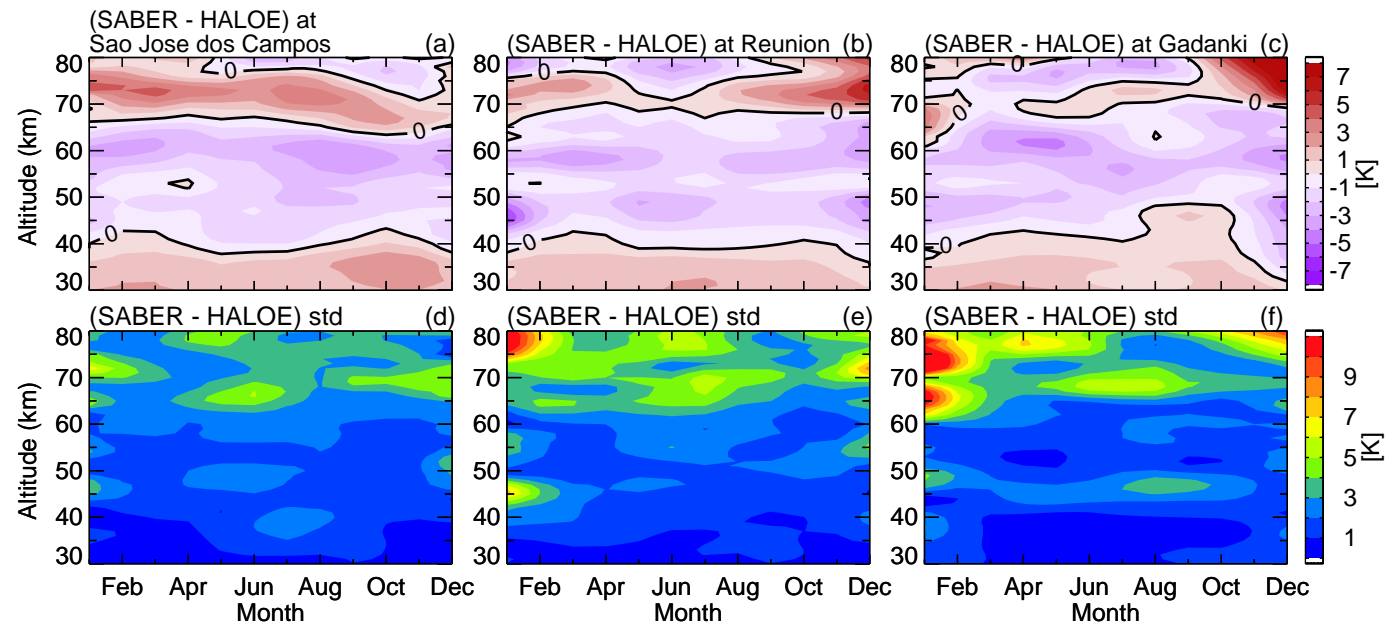

Fig. 3. Monthly mean temperature differences observed between SABER and HALOE over São José dos Campos, Gadanki and Reunion locations. Respective standard deviations are shown in the lower panels.

systematically $1-3 \mathrm{~K}$ colder than the SABER mean temperatures between 30 and $40 \mathrm{~km}$, and 70 and $80 \mathrm{~km}$. Note that we have considered data up to $80 \mathrm{~km}$ in case of satellite observations and above may be bias due to tidal effects. In addition, the HALOE mean temperatures are $2-4 \mathrm{~K}$ warmer than SABER measurements between 40 and $65 \mathrm{~km}$. Standard deviations between two measurements are smaller below $60 \mathrm{~km}$ which are less than $3 \mathrm{~K}$; however, the standard deviation rises to $5-7 \mathrm{~K}$ between 60 and $70 \mathrm{~km}$ except on a few occasions. From this exercise, we can make reasonable assumption that we can combine these two measurements, which provides us an opportunity to study the long-term trends in the middle atmosphere.

Figure 4 shows the time-altitude cross-sections of the monthly-mean temperatures obtained through a combination of HALOE (1992-2002) and SABER (2003-2011) observations at São José dos Campos, Reunion, and Gadanki LIDAR locations. While HALOE measurements extend up to the year 2005, we have only considered up to the year 2002, and have used SABER measurements from 2003. The small differences are found in the time series of monthly temperature profiles at higher altitudes $(>75 \mathrm{~km})$. These small differences could be due to the fact that the satellite data represents the integrated contribution of a deep atmospheric layer and takes into account contributions of layers in the middle and upper stratosphere with different smoothing layers are considered satellite to satellite. It is clear that the differences are not significant below $70 \mathrm{~km}$ and thus we combined the two satellite datasets to further investigate the long-term variability.

\subsection{Intrinsic Mode Function (IMF) analysis}

Before applying the regression analysis, first we check what periods are dominant in the long-term monthly temperature datasets. We use a new data analysis technique, which is based on the empirical mode decomposition (EMD) method, which generates a collection of intrinsic mode functions (IMF) (Huang and $\mathrm{Wu}, 2008$ ). This method naturally decomposes nonlinear oscillatory patterns into a number of characteristics IMF components. The decomposition is based on the direct extraction of the energy associated with various intrinsic time-scales, which are most important parameters of the system (Zhen-Shan and Xian, 2007). Higher frequency oscillations are captured in the first mode and subsequent modes have successively lower average frequencies. Detailed methodology of extracting IMFs from time series data is provided in Kishore et al. (2012). The main advantage of this method is that sensitivity to local details can exploited to identify periodic or quasi-periodic background signals.

The monthly temperature perturbation is decomposed into seven intrinsic mode functions (IMF) by the EMD method and the amplitude spectrum of the temperature perturbation and each resultant IMF is calculated using Lomb-Scargle analysis and is shown in the Fig. 5. For these figures, the selected altitude is $40 \mathrm{~km}$ from São José dos Campos monthly temperature datasets. As shown on the left side of the Fig. 5, each IMF component indicates temperature oscillations at a different time-scale. The Lomb Scargle Periodogram calculated from each IMF component shows the amplitude spectra as a function of oscillation period, and is plotted on the right side of the Fig. 5. The $90 \%$ confidence level of each periodogram is indicated with a horizontal dashed line. From the Figure (first from top), the dominant peaks near the SAO, AO, QBO, ENSO, and solar cycle and be clearly noticed. The solar cycle peak is broad ranging from 10 12 year period. The SAO (6 months) and AO (12 months) periods are present in first IMF and second IMFs, respectively. The third IMF shows QBO periods, which ranges between 23 to 30 months, the fifth IMF shows the ENSO 


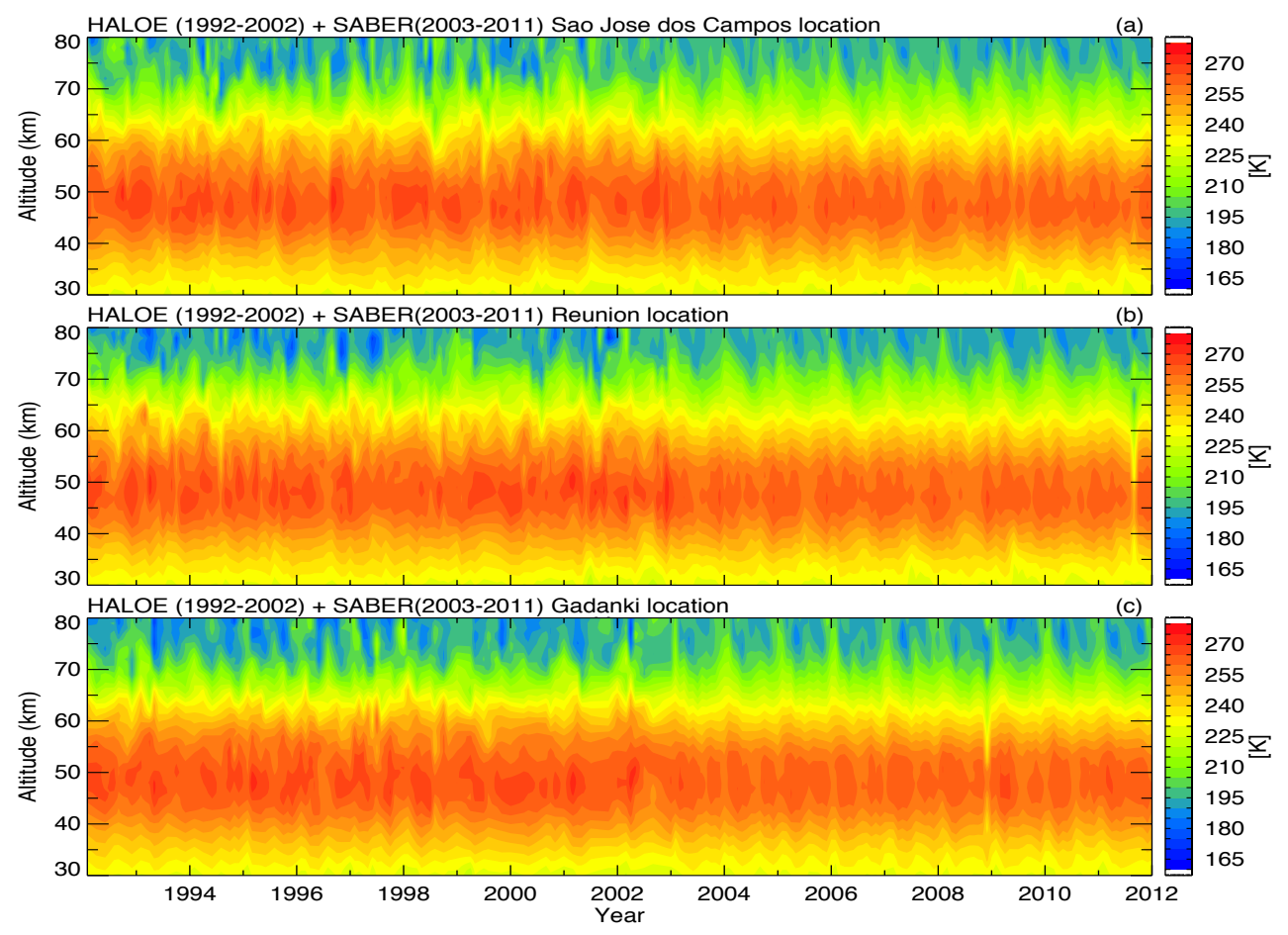

Fig. 4. Monthly mean temperature contours constructed using HALOE (1992-2002) and SABER (2003-2011) measurements over (a) São José dos Campos, (b) Reunion, and (c) Gadanki locations.

periods, which ranges between 52-64 months, and seventh IMF shows the solar cycle, which has an approximate 11year period. As already mentioned, the solar cycle period is little broad enough and observed that these periods appears throughout the stratosphere and mesospheric altitudes at all the stations though their amplitudes vary with respect to altitude and from station to station. The following subsections detail the individual analyses performed for all the three stations for each of the long-period variations.

\subsection{SAO, AO, QBO and ENSO oscillations}

Figures 6-8 show the amplitude (top) and phase (bottom) of the SAO, AO, QBO (26 months), ENSO (60 months) and solar (132 months) periods at each altitude derived from 35 to $65 \mathrm{~km}$ LIDAR measurements (red) and satellite measurements from 20 to $80 \mathrm{~km}$ (black) over São José dos Campos, Reunion and Gadanki, respectively. Horizontal bars represent the standard deviations at each altitude, which are a measure of the composite variability. In general, the oscillation amplitudes in the overlapping regions between the LIDAR and satellite measurements are quite comparable. The SAO and AO amplitudes observed by São José dos Campos LIDAR and satellite measurements (Fig. 6) both show smaller amplitudes in the order of $1-2 \mathrm{~K}$ below $65 \mathrm{~km}$. Using SABER measurements, Huang et al. (2006) reported the temperature amplitudes of $\mathrm{SAO}$ over $48^{\circ} \mathrm{S}-48^{\circ} \mathrm{N}$ for the altitudes 15 to $95 \mathrm{~km}$. For the latitude of $\sim 23^{\circ} \mathrm{S}$, they observed the maximum SAO amplitude observed at $75 \mathrm{~km}$, and minimum at $\sim 82 \mathrm{~km}$. We observe comparable SAO amplitude peaks with maximum amplitude at $72 \mathrm{~km}$. The difference between LIDAR and satellite amplitudes is less than $0.3 \mathrm{~K}$ at most of the altitudes for both SAO and AO. Compared to the $\mathrm{SAO}$, the observed $\mathrm{AO}$ amplitude is higher in the stratosphere and mesosphere. The phases of the SAO and AO observed by both LIDAR and satellite measurements show a downward progression below $60 \mathrm{~km}$, and above that altitude no clear phase progression is seen. Using 14 years of São José dos Campos LIDAR temperature data, Batista et al. (2009) also observed a peak in the amplitude of SAO near $60 \mathrm{~km}$.

We also obtained the amplitudes and phases of QBO with a 30-month period (figure not shown). The QBO amplitudes with 26 and 30-month periods are similar below $60 \mathrm{~km}$. The 26-month QBO case has a $\sim 1.3 \mathrm{~K}$ amplitude peak at $\sim 70 \mathrm{~km}$. São José dos Campos QBO (26-month) amplitudes observed from LIDAR are little larger than the amplitudes observed from the satellites. ENSO-period amplitudes observed below $45 \mathrm{~km}$ are $\sim 1 \mathrm{~K}$ in both LIDAR and satellite measurements. Large differences in the solar component amplitudes are noticed between LIDAR and satellite observations. Details of solar component along with QBO and ENSO will be discussed in Sect. 4.4.

Figure 7 shows amplitudes and phase profiles of the SAO, $\mathrm{AO}, \mathrm{QBO}, \mathrm{ENSO}$ and solar oscillations at Reunion obtained using LIDAR and satellite measurements. There are two 

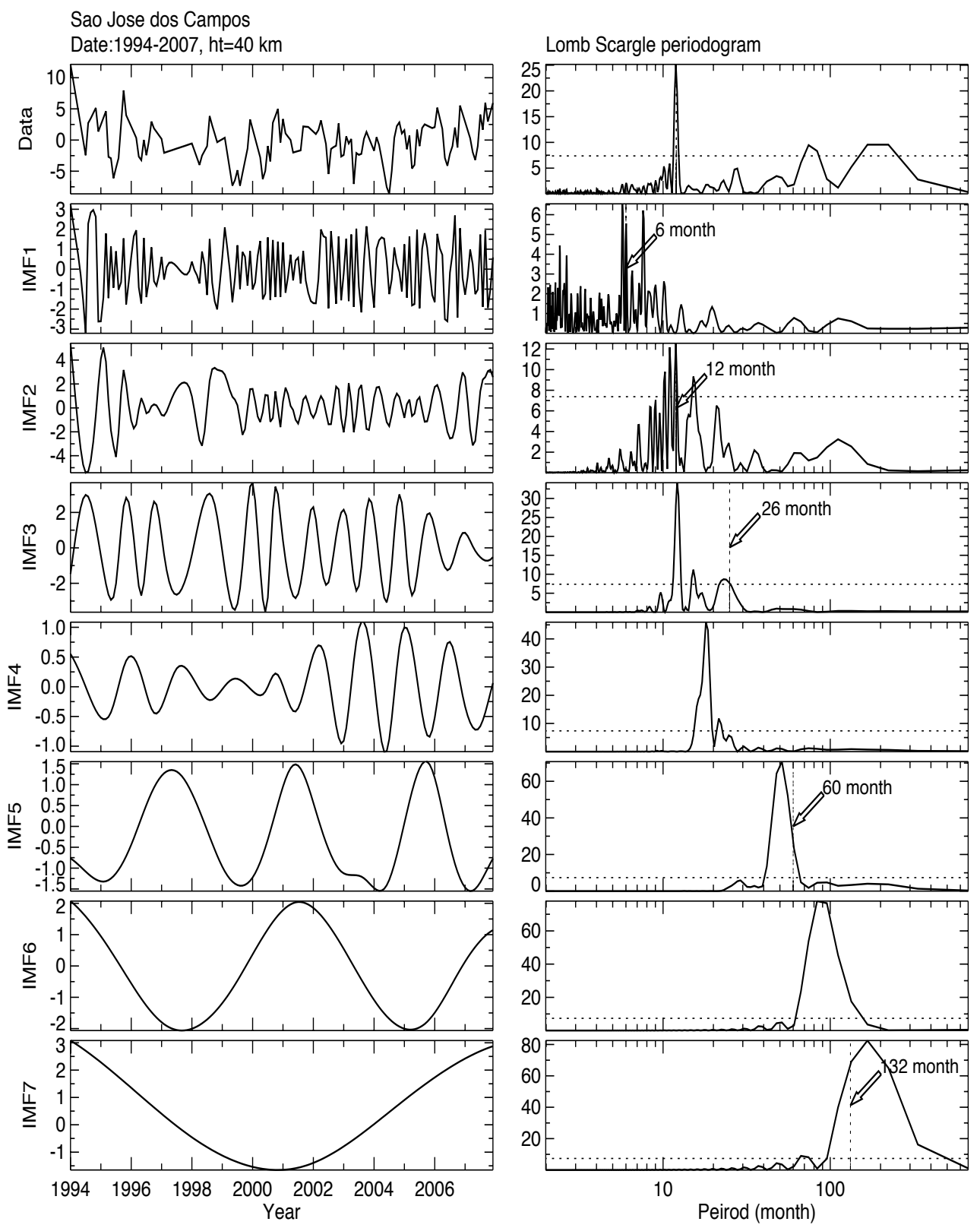

Fig. 5. Various IMFs obtained for temperature anomalies over São José dos Campos location (left panels) and corresponding LS periodograms (right panels). Dashed horizontal line shows $90 \%$ confidence level.

peaks observed in the SAO profile, one in the lower mesosphere $(\sim 59 \mathrm{~km})$ and another in the mesosphere $(\sim 75 \mathrm{~km})$. Dou et al. (2009) also observed SAO peak amplitude at altitudes $\sim 58 \mathrm{~km}$, and $\sim 75 \mathrm{~km}$ using SABER (at $22^{\circ} \mathrm{S}$ ) temperature measurements. The maxima in the Reunion AO amplitude profile from LIDAR measurements resides at approximately $42 \mathrm{~km}$ and is $1.71 \pm 0.16 \mathrm{~K}$ in magnitude; however, $\mathrm{AO}$ amplitudes at $42 \mathrm{~km}$ from satellite measurements are $0.78 \pm 0.11 \mathrm{~K}$ in magnitude. Dou et al. (2009) observe similar AO maximum amplitude at around $40 \mathrm{~km}$ using SABER and Reunion LIDAR. The observed LIDAR and satellite
SAO amplitudes agree morphologically with those published by Remsberg et al. (2002) based on 9.5 years of HALOE measurements, which covered between $40^{\circ} \mathrm{S}$ to $40^{\circ} \mathrm{N}$ from 32 to $80 \mathrm{~km}$ altitude. Note that SAO temperature amplitudes are little higher than $\mathrm{AO}$ temperature amplitudes in the lower mesosphere. QBO amplitudes at 26 and 30 months (figure not shown) show smaller amplitudes than SAO and AO. Note that ENSO amplitudes observed with LIDAR are in very good comparison with the satellite measurements. The phase profiles do not exhibit any particular pattern of variation with 

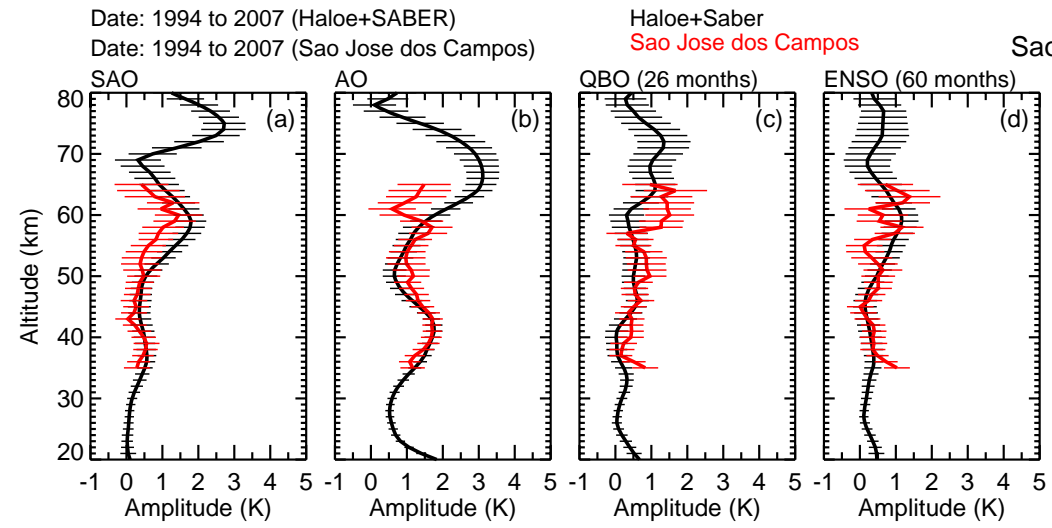

Sao Jose dos Campos
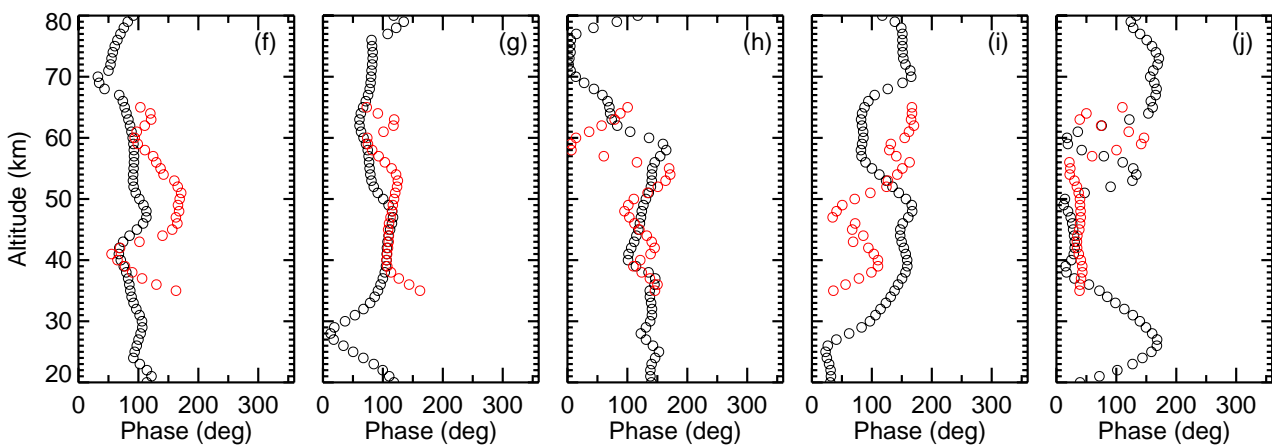

Fig. 6. Amplitudes observed in (a) SAO, (b) AO, (c) QBO (26 months), (d) ENSO (60 months), and (e) solar (132 months) over São José dos Campos location obtained using combined measurements of HALOE and SABER (1994-2007). Amplitudes observed using Lidar located at São José dos Campos during the same period is also superimposed in respective panels. Corresponding phases are shown in panels (f)-(j), respectively. The horizontal bars indicate 2-sigma error bars.

respect to altitude. SAO phase profiles show downward phase propagation.

The profiles of amplitudes and phases of SAO, AO, QBO (26 months), ENSO and solar cycle observed with LIDAR and satellite measurements over Gadanki are shown in Fig. 8. In general, the amplitudes and phases for all the oscillations compare well between the LIDAR and satellite measurements. Note that the amplitudes of these oscillations are small when compared to the amplitudes observed at the other two stations. The variation pattern in the profiles differs significantly from one to the other. The difference between the solar component from satellite and LIDAR measurements is smaller than the other two locations. As evident in Fig. 7, the difference in the solar component is fairly large at Reunion. Solar component fluctuations are larger at higher altitudes. In addition, the standard deviation values are larger in solar component as compared with the other oscillations. In general, the amplitudes and phases of these oscillations match well between the ground-based LIDAR and the satellite measurements. This suggests that satellite measurements can be used to investigate these large-scale oscillations across the globe. Both profiles show agreement within the error limits in the height region of 30-65 km. However, some differences are found in the profiles at higher altitude levels. The spatial smoothing of the satellite data grid may increase the standard deviation. The differences may also due to the time mean asymmetries in the winter stratosphere (stationary planetary waves), combined with the limited lidar sampling. In addition, the tidal waves may cause significant tidal aliasing to the oscillations (SAO, AO, QBO, and ENSO) derived from the LIDAR datasets, especially in the upper stratosphere and lower mesosphere.

\subsection{QBO, ENSO and Solar variations in temperature}

Figure 9 shows the temperature response to the QBO, ENSO and 11-year solar cycle derived from the regression analysis using the time series of satellite and LIDAR measurements as a function of altitude. The 2-sigma uncertainty (standard deviation) in the QBO, ENSO, and 11-year response from LIDAR (in red horizontal bars) are larger than those from satellite (in black horizontal bars) by about $40-65 \%$ depending on altitude. Variability in each climate oscillation is found to be larger at higher altitude. The patterns in the QBO coefficient from both LIDAR and satellite measurements are similar in the overlapping region. In addition, we found that the QBO response is larger above $60 \mathrm{~km}$, and is relatively smaller in the lower altitude levels. Inter-annual variability 

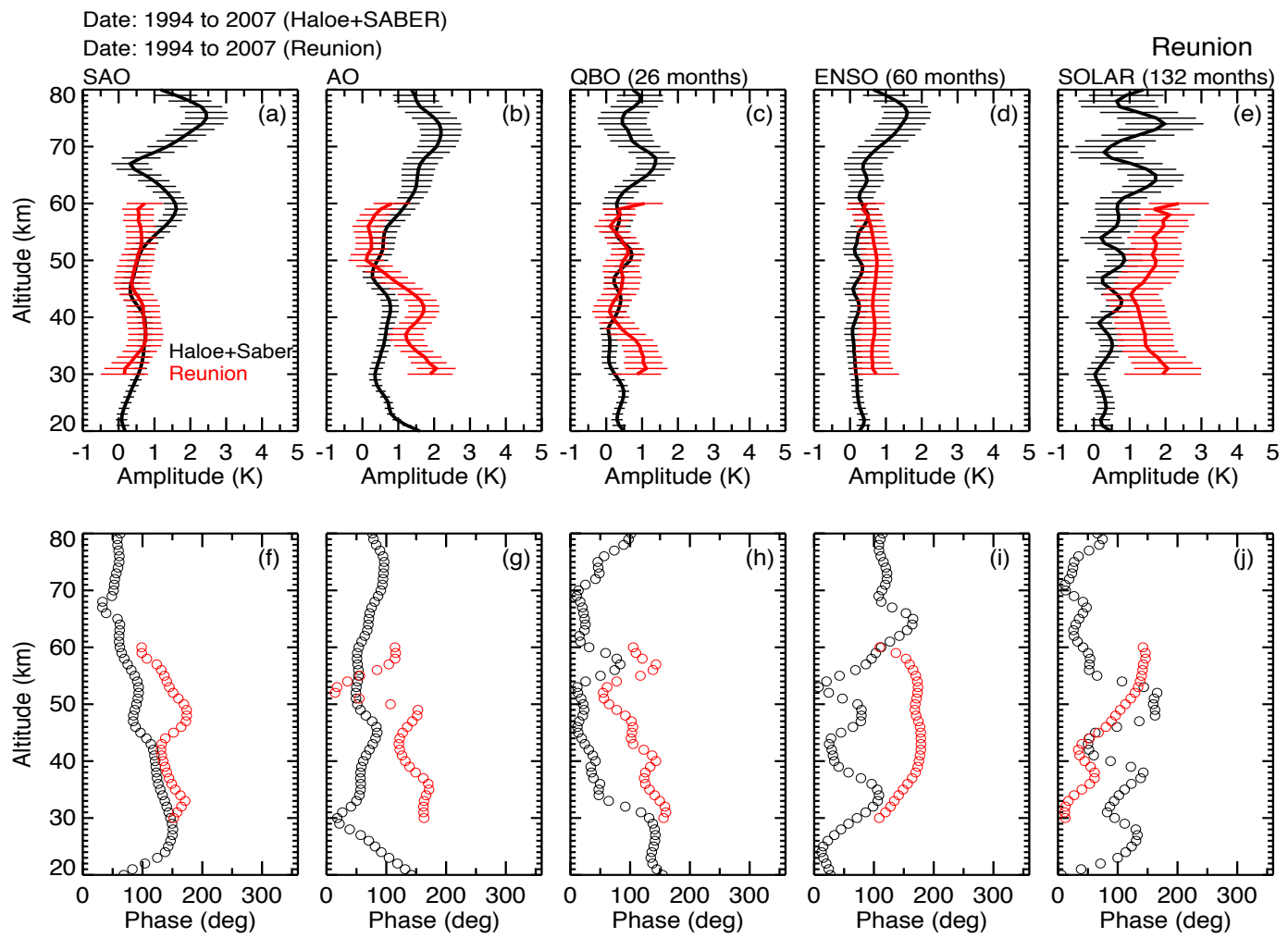

Fig. 7. Same as Fig. 6 but over Reunion location.

of temperature and zonal winds in the tropical stratosphere are strongly influenced by the QBO Baldwin et al. (2001). A strong ENSO positive maximum of $0.75 \mathrm{~K} / \mathrm{SOI}$ was observed at $50 \mathrm{~km}$, and a strong a negative minimum of $0.5 \mathrm{~K} / \mathrm{SOI}$ was observed near $60 \mathrm{~km}$ in the Gadanki LIDAR temperature datasets. The location and magnitude of the negative ENSO minima from the LIDAR and satellite are quite comparable. It is worth to quote recent study by $\mathrm{Li}$ et al. (2013) which reveals (their Fig. 2) negative temperature response in the troposphere and stratosphere and positive response in the mesosphere in WACCAM 3.5, but negative between 20 and $25 \mathrm{~km}$ and 40 and $50 \mathrm{~km}$, slight positive response between 30 and $40 \mathrm{~km}$, and strong positive response between 60 and $75 \mathrm{~km}$ in SABER observations. If we see carefully our Figs. 6-8, slight positive response between 30 and $40 \mathrm{~km}$ at all the locations and positive response between 60 and $75 \mathrm{~km}$ is also noticed in our observations similar to that reported in Li et al. (2013) for Reunion and São José dos Campos but not over Gadanki. The differences might be due to different time period and also considering the zonal means in their study.

The monthly analysis of these datasets reveals three different types of temperature signatures, following three distinct vertical shapes that are associated with three different latitude bands. All the three LIDARs reveal similar and significant negative solar flux coefficients, which turn to positive solar coefficients above $55 \mathrm{~km}$ altitude region. Using
Gadanki LIDAR, note that Sridharan et al. (2009) also observed similar negative solar flux values in the stratospheric region, which turn to positive solar coefficient values above $60 \mathrm{~km}$. In some altitudes a positive response can be noted, however the significance is not sufficient in the upper stratosphere. However, a signature of 1 to $2 \mathrm{~K} / 100 \mathrm{sfu}$ appears in the upper stratosphere and lower mesosphere (45 to $65 \mathrm{~km}$ ). In the case of the satellite solar flux, the coefficients are similar with significant positive values in between 40 to $60 \mathrm{~km}$ altitudes, which exhibit a maximum of $1.5 \mathrm{~K} / 100 \mathrm{sfu}$ at around $55 \mathrm{~km}$. Remsberg and Deaver (2005) observed the 11-year solar cycle in the upper stratosphere and mesosphere over the period 1991 to 2004 for latitude zones from $40^{\circ} \mathrm{N}$ to $40^{\circ} \mathrm{S}$ using HALOE measurements. They found 11 -year solar cycle amplitudes between 0.5 and $1.7 \mathrm{~K} / 100$ sfu in their temperature versus pressure time series. Recently, Fadnavis et al. (2012) estimated the response of temperature to solar variability in $0-30^{\circ} \mathrm{N}$ latitude bands and reported a positive response in the upper stratosphere and mesosphere regions $(50-75 \mathrm{~km})$. They found solar variability $\sim 0.5-1 \mathrm{~K} / 100 \mathrm{sfu}$ below $70 \mathrm{~km}$ and $1 \mathrm{~K} / 100 \mathrm{sfu}$ above $70 \mathrm{~km}$ in the tropics. Note that the derived solar flux coefficient of temperature depends on the length of the datasets. A similar response in HALOE observations was reported by Beig (2011b) and Fadnavis et al. (2012). It may be concluded that the satellite measurements reported are for zonal means. However, satellite 

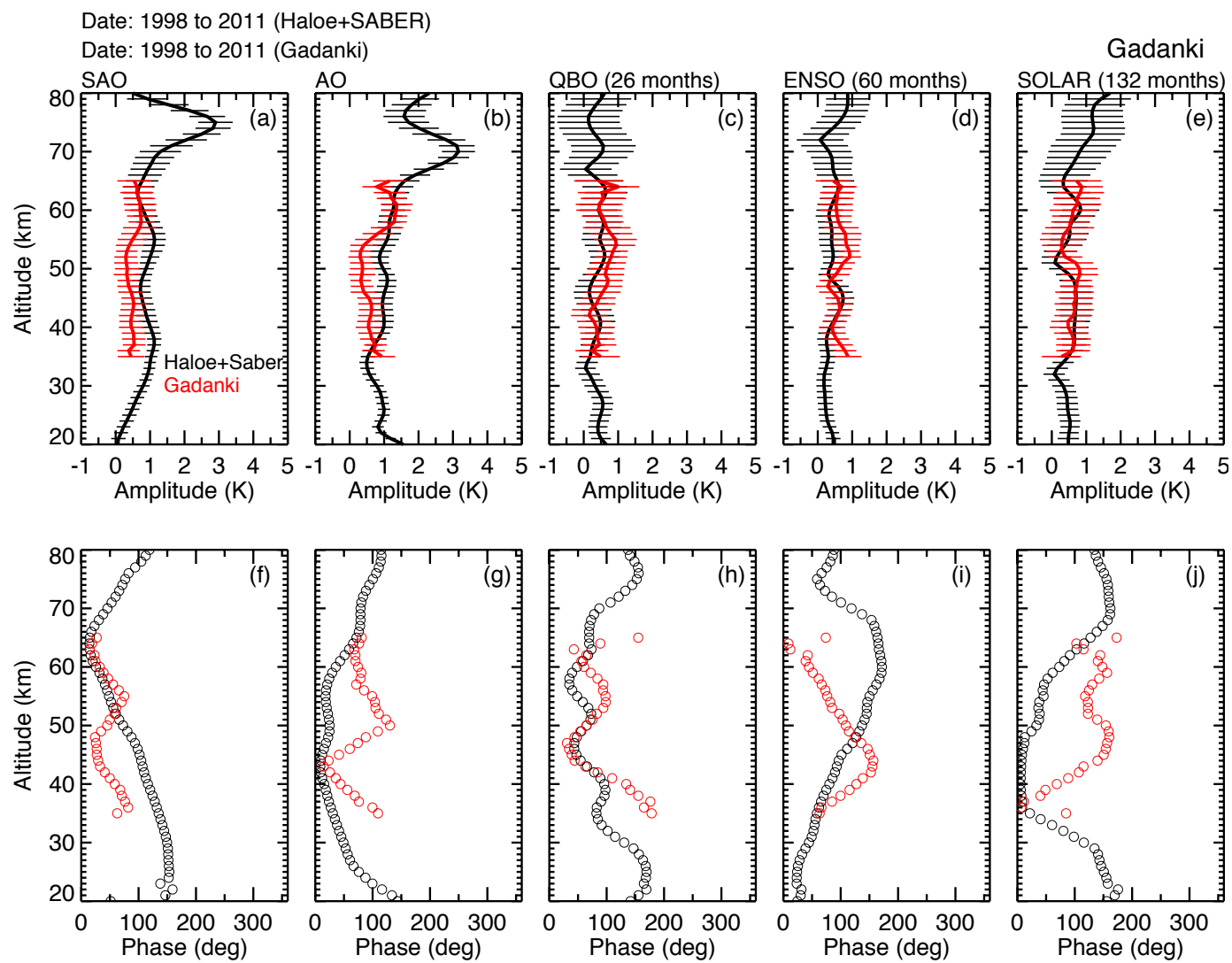

Fig. 8. Same as Fig. 6 but over Gadanki location during 1998-2011.

observations at the specific LIDAR locations show both positive and negative response similar to the LIDAR measurements shown in the present study. Using three independent temperature datasets, Keckhut et al. (2005) observed a positive response to the solar coefficient in the stratosphere between $1-2 \mathrm{~K}$ in the tropics and large negative in mid-latitudes regions. Recently, using three long-term lidar datasets covering nearly two solar cycles, $\mathrm{Li}$ et al. (2011) revealed the significant different temperature response to solar cycles at different locations and different period. The stratospheric response to the solar cycle is attributed to direct absorption of solar radiation by ozone (McCormack and Hood, 1996; Larkin et al., 2000). Ramaswamy et al. (2001) calculated the solar flux coefficients using nadir-viewing satellite observations from 1979 to 1995 , and showed solar component of the order of $0.5-1.0 \mathrm{~K}$ throughout most of the low-latitude $\left(30^{\circ} \mathrm{N}-30^{\circ} \mathrm{S}\right)$ stratosphere, with a maximum near the $40 \mathrm{~km}$ altitude level. The solar cycle signature in stratospheric temperatures does not need to be uniform over the globe or identical at all altitudes. This has been made clear on the horizontal scale from the work of Labitzke and van Loon (1997), on the vertical scale from the work of Chanin and Keckhut (1991), and may be attributable to the role of planetary waves.

\subsection{Long-term trends}

The altitude profiles of the estimated linear-trend coefficients, and their associated two-sigma error limits are plotted in Fig. 10. Figure 10a shows the trends obtained over the São José dos Campos using 14 years of LIDAR data (19942007) along with the trends obtained with satellite temperature measurements. Both measurements show cooling trends between 40 and $60 \mathrm{~km}$ altitude region with varying magnitudes of about $\sim 0.25-2.9 \mathrm{~K} \mathrm{decade}^{-1}$. The LIDAR temperature cooling trends are about $0.32 \pm 0.27 \mathrm{~K} \mathrm{decade}^{-1}$, $1.78 \pm 0.38 \mathrm{~K} \mathrm{decade}^{-1}, 0.41 \pm 0.59 \mathrm{~K} \mathrm{decade}^{-1}$ at 40,50 , and $60 \mathrm{~km}$ altitude levels, respectively. Using the simple least squares linear fit method, Batista et al. (2009) reported the temperature cooling trends over São José dos Campos as $1.09 \pm 0.57 \mathrm{~K} \mathrm{decade}^{-1}, 2.29 \pm 0.66 \mathrm{Kdecade}^{-1}$, and $1.42 \pm 0.98 \mathrm{~K} \mathrm{decade}^{-1}$ for 40,50 , and $60 \mathrm{~km}$ altitudes, respectively. The quasi-periodic oscillations are not considered in their analysis, and might be one of the reasons for observing stronger cooling trends. 

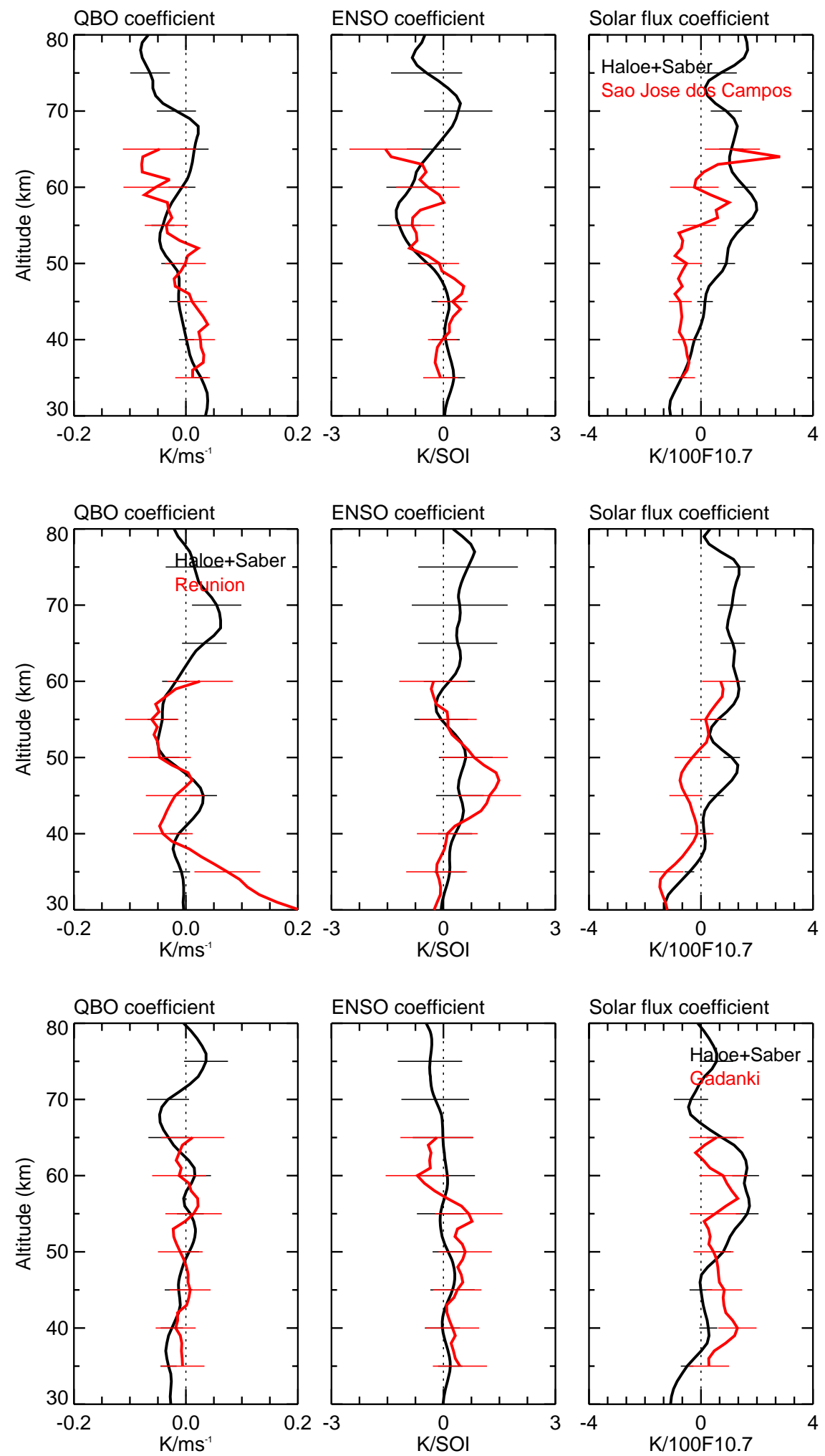

Fig. 9. Coefficients observed in QBO (left panels), ENSO (middle panels) and Solar (right panels) using combined measurements of HALOE and SABER over São José dos Campos (top panels), Reunion (middle panels) and Gadanki (bottom panels) locations. Coefficients observed using respective Lidars at different locations are also superimposed. 

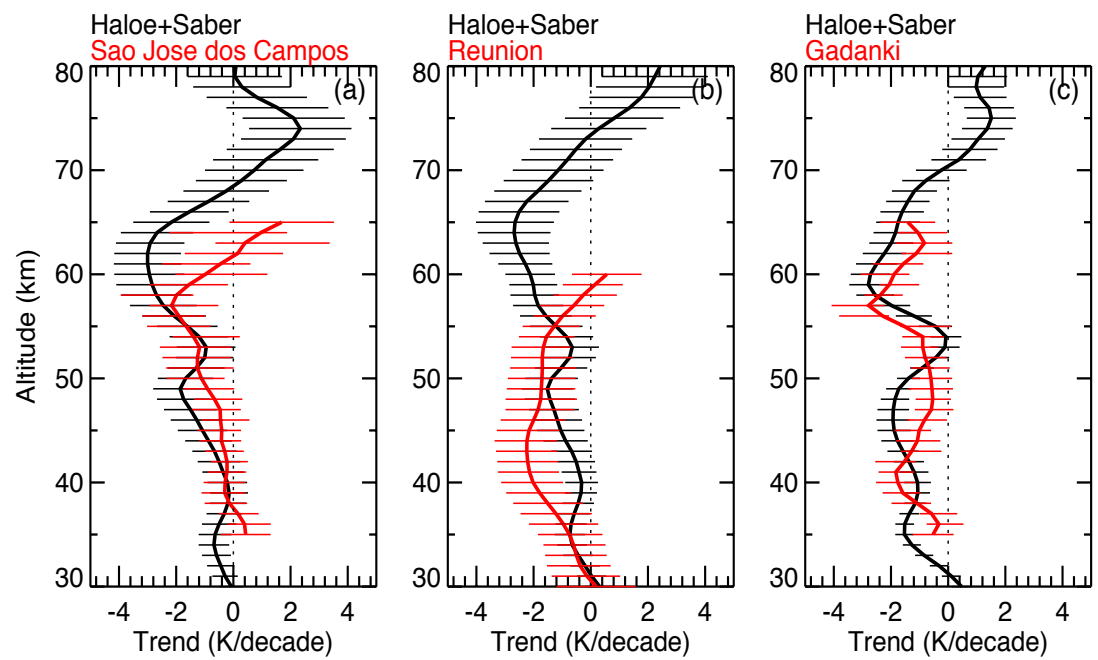

Fig. 10. Long-term trends observed at different altitudes obtained using combined measurements of HALOE and SABER measurements over (a) São José dos Campos, (b) Reunion, and (c) Gadanki locations. Trends observed using Lidars at respective locations are also superimposed.

Table 1. Long-term trends observed using different lidars along with that those observed from satellite observations over respective locations. The values reported in Remsberg (2009) are also provided. The \pm 1 sigma uncertainties (standard deviations) are in parenthesis.

\begin{tabular}{|c|c|c|c|}
\hline $\begin{array}{l}\text { Altitude } \\
(\mathrm{km})\end{array}$ & $\begin{array}{l}\text { São José dos Campos } \\
\left(23^{\circ} \mathrm{S}, 46^{\circ} \mathrm{W}\right) \\
1994-2007\left(\mathrm{~K} \mathrm{dec}^{-1}\right)\end{array}$ & $\begin{array}{l}\text { HALOE + SABER } \\
23 \pm 5^{\circ} \mathrm{S} \\
1992-2011\left(\mathrm{~K} \mathrm{dec}^{-1}\right)\end{array}$ & $\begin{array}{l}\text { Remsberg (2009) } \\
25 \pm 5^{\circ} \mathrm{S} \\
1991-2005\left(\mathrm{~K} \mathrm{dec}^{-1}\right)\end{array}$ \\
\hline $\begin{array}{l}40 \\
50 \\
60\end{array}$ & $\begin{array}{l}-0.31(0.40) \\
-1.32(0.55) \\
-0.42(0.58)\end{array}$ & $\begin{array}{l}-0.21(0.35) \\
-1.67(0.40) \\
-2.64(0.62)\end{array}$ & $\begin{array}{l}-0.7(0.18) \\
-1.0(0.17) \\
-0.7(0.18)\end{array}$ \\
\hline $\begin{array}{l}\text { Altitude } \\
(\mathrm{km})\end{array}$ & $\begin{array}{l}\text { Reunion }\left(20.8^{\circ} \mathrm{S}\right) \\
1994-2007 \\
\left(\mathrm{~K} \mathrm{dec}^{-1}\right)\end{array}$ & $\begin{array}{l}\text { HALOE }+ \text { SABER } \\
21 \pm 5^{\circ} \mathrm{S} \\
1992-2011\left(\mathrm{~K} \mathrm{dec}^{-1}\right)\end{array}$ & $\begin{array}{l}- \\
- \\
-\end{array}$ \\
\hline $\begin{array}{l}40 \\
50 \\
60\end{array}$ & $\begin{array}{l}-2.01(0.54) \\
-1.52(0.65) \\
-0.56(0.55)\end{array}$ & $\begin{array}{l}-0.32(0.23) \\
-1.37(0.40) \\
-2.12(0.48)\end{array}$ & $\begin{array}{l}- \\
- \\
-\end{array}$ \\
\hline $\begin{array}{l}\text { Altitude } \\
(\mathrm{km})\end{array}$ & $\begin{array}{l}\text { Gadanki }\left(13.5^{\circ} \mathrm{N}\right) \\
1998-2011\left(\mathrm{~K} \mathrm{dec}^{-1}\right) \\
\left(\mathrm{K} \mathrm{dec}^{-1}\right)\end{array}$ & $\begin{array}{l}\text { HALOE + SABER } \\
13.5 \pm 5^{\circ} \mathrm{N} \\
1992-2011\left(\mathrm{~K} \mathrm{dec}^{-1}\right)\end{array}$ & $\begin{array}{l}\text { Remsberg (2009) } \\
10 \pm 5^{\circ} \mathrm{N} \\
1991-2005\left(\mathrm{~K} \mathrm{dec}^{-1}\right)\end{array}$ \\
\hline $\begin{array}{l}40 \\
50 \\
60\end{array}$ & $\begin{array}{l}-1.84(0.38) \\
-0.69(0.51) \\
-2.21(0.45)\end{array}$ & $\begin{array}{l}-1.08(0.35) \\
-1.39(0.32) \\
-2.72(0.51)\end{array}$ & $\begin{array}{l}- \\
-0.7(0.17) \\
-1.2(0.16)\end{array}$ \\
\hline
\end{tabular}

Profiles of estimated linear trend coefficients over Reunion using 14 years of lidar data (1994-2007) along with the trends obtained with satellite temperature measurements are shown in Fig. 10b. Both measurements again show cooling trends between the 30 and $60 \mathrm{~km}$ altitude regions with varying magnitudes. Maximum cooling trends in the LIDAR measurements are observed nearly at $43 \mathrm{~km}$ altitude. The cooling trend is $0.8 \pm 0.6 \mathrm{~K} \mathrm{decade}^{-1}$ near $35 \mathrm{~km}$, which increases with altitude and attains a peak near $43 \mathrm{~km}$. However, a similar trend profile is not observed in the satellite measurements. Remsberg and Deaver (2005) reported that temperature trends over $40^{\circ} \mathrm{S}-40^{\circ} \mathrm{N}$ (10 degree width) for the altitudes ranging from 40 to $80 \mathrm{~km}$ showed a cooling trend between 0.5 to $2.25 \mathrm{~K} \mathrm{decade}^{-1}$ at $\sim 23^{\circ} \mathrm{S}$ latitude region with the maximum cooling trend near $63 \mathrm{~km}$ altitude. The maximum cooling trend is observed in our analysis is at about $2.7 \pm 1.1 \mathrm{~K} \mathrm{decade}^{-1}$ at $64 \mathrm{~km}$ altitude, which is consistent with that reported by Remsberg and Deaver (2005).

Figure 10c shows the profile of temperature trend observed over Gadanki (1998-2011) using both LIDAR and 
satellite measurements along with their respective two sigma error limits. In general, cooling trends observed in the LIDAR measurements are $0.43 \pm 0.62 \mathrm{~K}$ decade $^{-1}$ near $35 \mathrm{~km}$. This cooling trend increases with altitude and attain values of $2.83 \pm 1.1 \mathrm{~K} \mathrm{decade}^{-1}$ near $38 \mathrm{~km}$ then decreases to $1.36 \pm 0.81 \mathrm{~K} \mathrm{decade}^{-1}$ near $48 \mathrm{~km}$. Another stronger cooling is observed around $56 \mathrm{~km}$ over Gadanki. The maximum cooling trend at $38 \mathrm{~km}$ is consistent with earlier analysis of SAGE II data, which showed the cooling trend peak at $40 \mathrm{~km}$ (Newchurch et al., 2000). Recently, Sridharan et al. (2009) observed stronger cooling at $37 \mathrm{~km}$ and $57 \mathrm{~km}$ using Gadanki LIDAR data. The vertical trend profile from satellite measurements exhibits a cooling trend of $\sim 1.3 \mathrm{~K} \mathrm{decade}^{-1}$ near $52 \mathrm{~km}$, which it increases with altitude and attains a peak of $-3.85 \mathrm{~K} \mathrm{decade}^{-1}$ near $58 \mathrm{~km}$. The temperature trends start to decrease above $58 \mathrm{~km}$ and turns into slight warming trend at around $70 \mathrm{~km}$ altitude. The observed maximum cooling trend in our analysis is relatively low compared an earlier analysis of HALOE data (Randel et al., 1999). The difference may be due to the selection of a different width for our latitude belt used for averaging the data.

The pattern of temperature trends in equatorial regions $\left(13^{\circ} \mathrm{N}-23^{\circ} \mathrm{S}\right)$ from the three LIDARs and satellite measurements agree well with the cooling trends found in the upper stratosphere and lower mesosphere altitudes. However, differences are also observed at some altitude levels. The observed quantitative differences might be due to differences in chosen time period and the fact that the satellite measurements are averaged over a latitudinal grid. The difference could also be due to instrumental bias inducing changes in the monthly-mean measurements. The strongest cooling from satellite measurements at two locations (São José dos Campos and Reunion) are observed at around $62 \mathrm{~km}$, whereas in the case of Gadanki location, the strongest cooling trend is at approximately $58 \mathrm{~km}$. The LIDAR trends of São José dos Campos (Fig. 10a) and Reunion (Fig. 10b) at these two latitudes tend to be out of phase with satellite observed trends above $56 \mathrm{~km}$ altitude level. Using HALOE satellite temperature measurements during 1992-2004, Fadnavis and Beig (2006) observed a stronger cooling trend around $35 \mathrm{~km}$ over the tropics $\left(0-30^{\circ} \mathrm{N}\right)$, which decreases near the stratopause. Using a series of rocketsonde and radiosonde data over the equatorial station, Beig and Fadnavis (2001) observed a negative trend of $2-3 \mathrm{~K} \mathrm{decade}^{-1}$ in the lower mesosphere and an increase in cooling to 5$6 \mathrm{~K} \mathrm{decade}^{-1}$ at $70 \mathrm{~km}$, with the two standard deviations error found to range from $\pm 0.5 \mathrm{~K} \mathrm{decade}^{-1}$ in the lower mesosphere to $\pm 1.3 \mathrm{~K} \mathrm{decade}^{-1}$ in the middle mesosphere.

Calculated long-term trend values at selected altitude levels are shown in Table 1. The trend values are shown for both individual LIDAR datasets and the combined HALOE and SABER satellite measurements (as depicted earlier in Fig. 10). The table summarises the representative trend values for the lower stratosphere $(40 \mathrm{~km})$, stratopause $(50 \mathrm{~km})$ and lower mesosphere $(60 \mathrm{~km})$ altitude regions. In general, the satellite measurements show higher values than the LIDAR observations. The results are found to be within the standard deviations for São José dos Campos and Reunion, especially for 40 and $50 \mathrm{~km}$ altitude levels. However, the results show a higher negative value for all the three sites from the satellite and the differences are found to be higher between LIDAR and satellites. The results are compared with the earlier observations shown by Remsberg (2009) and are found comparable for the LIDAR site, São José dos Campos and Gadanki.

\section{Summary and conclusions}

Using long-term temperature datasets from three LIDAR stations (São José dos Campos, Reunion, and Gadanki) from low $\left(23^{\circ} \mathrm{S}-13^{\circ} \mathrm{N}\right)$ latitudes, long-term trends observed in the temperatures are reported including $\mathrm{SAO}, \mathrm{AO}, \mathrm{QBO}, \mathrm{ENSO}$ and solar cycle oscillations in the stratosphere and mesosphere. The oscillations extracted from LIDARs are compared with those derived from the satellite (HALOE and SABER) observations. The main findings are summarised in the following:

1. In general, the climatological temperature structures observed from LIDARs are in good agreement with those observed from satellite observations. The maximum differences are $2-3 \mathrm{~K}$ in the stratosphere, and $4-6 \mathrm{~K}$ in the mesosphere.

2. Differences in the temperature profiles obtained using HALOE and SABER measurements are less in the overlapping period of observations, allowing us to make the longest possible time series from the satellite observations.

3. Amplitudes and phases of long period oscillations of SAO, AO, QBO, and ENSO agree well between those extracted from ground-based LIDARs and satellite borne observations. However, large differences are noticed in the solar component suggesting that length of the ground-based dataset is not yet sufficient to investigate the $\sim 11$ year cycle.

4. Both LIDAR and satellite measurements show a cooling trend at about $0.5-0.7 \mathrm{~K} \mathrm{decade}^{-1}$ between 40 and $55 \mathrm{~km}$. The LIDARs (São José dos Campos and Gadanki) standard deviations are with in the range of satellite standard deviations.

5. At all stations a change from cooling trend to warming trend occurs around $70 \mathrm{~km}$. Larger warming trends are noticed in northern location of Gadanki than the southern locations of São José dos Campos and Reunion.

6. The results below $70 \mathrm{~km}$ are in good agreement with those prior reported results, which confirms that the 
temperature trends and long-period oscillations derived from satellite measurements are comparable with ground-based observations, suggesting that the trends can be extracted in the tropical latitudes globally using satellite measurements.

However, caution is advised while interpreting the results above $70 \mathrm{~km}$ altitude. Investigations on the long-term trends in the temperature covering the entire middle atmosphere are in progress.

Acknowledgements. We would like to thank staff of three lidar locations for lidar operations. We also thank HALOE and SABER teams for providing datasets through their ftp sites.

Topical Editor C. Jacobi thanks S. P. Namboothiri and one anonymous referee for their help in evaluating this paper.

\section{References}

Baldwin, M. P. and O'Sullivan, D.: Stratospheric effects of ENSOrelated tropospheric circulation anomalies, J. Climate, 8, 649667, 1994.

Baldwin, M. P., Gray, L. J., Dunkerton, T. J., Hamilton, K., Haynes, P. H., Randel, W. J., Holton, J. R., Alexander, M. J., Hirota, I., Horinouchi, T., Jones, D. B. A., Kinnersley, J. S., Marquardt, C., Sato. K., and Takahashi, M.: The Quasi-biennial oscillation, Rev. Geophys., 39, 179-229, 2001.

Barnett, J. J. and Corney, M.: Middle atmosphere reference model derived from satellite data, Middle Atmosphere Program, in: Handbook for MAP, 16, 47-85, 1985.

Batista, P. P., Clemesha, B. R., and Simonich, D. M.: Tidal associated temperature disturbances observed at the middle atmosphere $(30-65 \mathrm{~km})$ by a Rayleigh lidar at $23^{\circ} \mathrm{S}$, Adv. Space Res., 41, 1408-1414, 2008.

Batista, P. P., Clemesha, B. R., and Simonich, M.: A 14-year monthly climatology and trend in the $35-65 \mathrm{~km}$ altitude range from Rayleigh Lidar temperature measurements at a low latitude station, J. Atmos. Sol. Terr. Phys., 71, 1456-1462, 2009.

Beig, G.: Long-term trends in the temperature of the mesosphere/lower thermosphere region: 1. Anthropogenic influences, J. Geophys. Res., 116, A00H11, doi:10.1029/2011JA016646, 2011a.

Beig, G.: Long-term trends in the temperature of the mesosphere/lower thermosphere region: 2. Solar response, J. Geophys. Res., 116, A00H12, doi:10.1029/2011JA016766, $2011 \mathrm{~b}$.

Beig, G. and Fadnavis, S.: In search of greenhouse signals in the equatorial middle atmosphere, Geophys. Res. Lett., 28, 46034606, 2001.

Beig, G., Keckhut, P., Lowe, R. P., Roble, R. G., Mlynczak, M. G., Scheer, J., Fomichev, V. I., Offermann, D., French, W. J. R., Shepherd, M. G., Semenov, A. I., Remsberg, E. E., She, C. Y., Lubken, F. J., Bremer, J., Clemesha, B. R., Stegman, J., Sigernes, F., and Fadnavis, S.: Review of mesospheric temperature trends, Rev. Geophys. Res., 41, 1015, doi:10.1029/2002RG000121, 2003.

Chanin, M. L. and Hauchecrone, A.: Lidar studies of temperature and density using Rayleigh scattering, MAP Handbook, 113, SCOSTEP, Urbana, IL, USA, 87-98, 1984.
Chanin, M. L. and Keckhut, P.: Influence on the middle atmosphere of the 27-day and 11-year solar cycles: Radiative and/or dynamical forcing?, J. Geomagn. Geoelectr., 43, 647-655, 1991.

Clemesha, B. R., Batista, P. P., and Simonich, D. M.: Long-term and solar cycle changes in the atmospheric sodium layer, J. Atmos. Sol. Terr. Phys., 13, 1673-1678, 1997.

Dou, X., Li, T., Xu, J., Liu, H. L., Xue, X., Wang, S., Leblanc, T., McDermid, I. S., Hauchecome, A., Keckhut, P., Bencherif, H., Heinselman, C., Steinbrecht, W., Mlynczak, M. G., and Russell III, J. M.: Seasonal oscillations of middle atmosphere temperature observed by Rayleigh lidars and their comparisons with TIMED/SABER observations, J. Geophys. Res., 114, D20103, doi:10.1029/2008JD011654, 2009.

Fadnavis, S. and Beig, G.: Seasonal variation of trend in temperature and ozone over the tropical stratosphere in the Northern hemisphere, J. Atmos. Sol. Terr. Phys., 68, 1952-1961, 2006.

Fadnavis, S., Beig, G., and Chakraborti, T.: Decadal solar signal in ozone and temperature through the mesosphere of Northern tropics, J. Atmos. Sol. Terr. Phys., 78-79, 2-7, 2012.

Funatsu, B. M., Claus, C., Keckhut, P., and Hauchrone, A.: Crossvalidation of Advanced Microwave Sounding Unit and lidar for long-term upper-stratospheric temperature monitoring, J. Geophys. Res., 113, D23108, doi:10.1029/2008JD010743, 2008.

Hervig, M. E., Russell III, J. M., Gordley, L. L., Drayson, S. R., Stone, K., Thompson, R. E., Gelman, M. E., McDermid, I. S., Hauchecorne, A., Keckhut, P., McGee, T. J., Singh, U. N., and Gross, M. R.: Validation of temperature measurements from the Halogen Occultation Experiment, J. Geophys. Res., 101, 1027710285, 1996.

Huang, F. T., Mayr, H. G., Reber, C. A., Russell, J. M., Mlynczak, M., and Mengel, J. G.: Stratospheric and mesospheric temperature variations for the quasi-biennial and semiannual (QBO and SAO) oscillations based on measurements from SABER (TIMED) and MLS (UARS), Ann. Geophys., 24, 2131-2149, doi:10.5194/angeo-24-2131-2006, 2006.

Huang, N. E. and Wu, Z.: A review on Hilbert-Huang Transform: the method and its applications on geophysical studies, Rev. Geophys., 46, RG2006, doi:10.1029/2007RG000228, 2008.

IPCC: Contribution of Working Group 1 to the Fourth Assessment Report of the Intergovernmental Panel on Climate Change, in: Climate Change 2007, The Physical Science Basis, edited by: Solomon, S., Qin, D., Manning, M., Chen, Z., Marquis, M., Avery, K. B., Tignor, M., and Miller H. L., Cambridge University Press, Cambridge, United Kingdom and New York, NY, USA, 2007.

Keckhut, P., Gelman, M. E., Wild, J. D., Tissot, F., Miller, A. J., Hauchecorne, A., Chanin, M. L., Fishbein, E. F., Gille, J., Rusell III, J. M., and Taylor, F. W.: Semidiurnal and diurnal temperature tides $(30-55 \mathrm{~km})$ : Climatology and effects on UARS lidar data comparisons, J. Geophys. Res., 101, 10299-10310, 1996.

Keckhut, P., McDermid, S., Swart, D., McGee, T., Godin Beekmann, S., Adriani, A., Barnes, J., Baray, J.-L., Bencherif, H., Claude, H., De Sarra, A., Fiocco, G., Hansen, G., Hauchecorne, A., Lablanc, T., Lee, C. H., Pal, S., Megie, G., Nakane, H., Neuber, R., Steinbrecht, W., and Thayer, J.: Review of ozone and temperature lidar validations performed within the framework of the network for the detection of stratospheric change, J. Environ. Monit., 6, 721-733, 2004. 
Keckhut, P., Cagnazzo, C., Chanin, M.-L., Claud, C., and Hauchecorne, A.: The 11-year solar-cycle effects on the temperature in the upper-stratosphere and mesosphere: Part I- Assessment of observations, J. Atmos. Sol. Terr. Phys., 67, 940-947, 2005.

Kishore, P., Velicogna, I., Venkat Ratnam, M., Jiang, J. H., and Madhavi, G. N.: Planetary waves in the upper stratosphere and lower mesosphere during 2009 Arctic major stratospheric warming, Ann. Geophys., 30, 1529-1538, doi:10.5194/angeo30-1529-2012, 2012.

Kishorekumar, G., Ratnam, M. V., Patra, A. K., Rao, S. V. B., and Russell, J.: Mean thermal structure of the low-latitude middle atmosphere studied using Gadanki Rayleigh lidar, Rocket, and SABER/TIMED observations, J. Geophys. Res., 113, D23106, doi:10.1029/2008JD010511, 2008.

Labitzke, K. and van Loon, H.: The signal of the 11-year sunspot cycle in the upper troposphere-lower stratosphere, Space Sci. Rev., 80, 393-410, 1997.

Lanzante, J. R., Klein, S. A., and Seidel, D. J.: Temporal homogenization of monthly radiosonde temperature data, Part I: methodology, J. Climate., 16, 224-240, 2003 a.

Lanzante, J. R., Klein, S. A., and Seidel, D. J.: Temporal homogenization of monthly radiosonde temperature data, Part II: trends, sensitivities, and MSU comparison, J. Climate., 16, 241-262, 2003 b.

Larkin, A., Haigh, J. D., and Djavidnia, S.: The effect of UV irradiance variations on the Earth's atmosphere, Space Sci. Rev., 94, 199-214, 2000.

Leblanc, T., McDermid, I. S., Hauchecorne, A., and Keckhut, P.: Evaluation of optimization of lidar temperature analysis algorithms using simulated data, J. Geophys. Res., 103, 6177-6187, 1998.

Li, T., Leblanc, T., and McDermid, I. S.: Interannual variations of middle atmospheric temperature as measured by the JPL lidar at Mauna Loa Observatory, Hawaii (19.5N, 155.6W), J. Geophys. Res., 113, D14109, doi:10.1029/2007JD009764, 2008.

Li, T., Leblanc, T., McDermid, I. S., Keckhut, P., Hauchecorne, A., and Dou, X.: Middle atmosphere temperature trend and solar cycle revealed by long-term Rayleigh lidar observations, J. Geophys. Res., 116, D00P05, doi:10.1029/2010JD015275, 2011.

Li, T., Calvo, N., Yue, J., Dou, X., Russell III, J. M., Mlynczak, M. G., She, C.-Y., and Xue, X.: Influence of ElNiño-Southern Oscillation in the mesosphere, Geophys. Res. Lett., 40, 32923296, doi:10.1002/grl.50598, 2013.

McCormack, J. P. and Hood, L. L.: Apparent solar cycle variations of upper stratospheric ozone and temperature: latitudinal and seasonal dependences, J. Geophys. Res., 101, 20933-20944, 1996.

Mertens, C. J., Mlynczak, M. G., Lopez-Puertas, M., Wintersteiner, P. P., Picard, R. H., Winick, J. R., Gordley, L. L., and Russell III, J. M.: Retrieval of mesospheric and lower thermospheric kinetic temperature from measurements of $\mathrm{CO}_{2} 15 \mu \mathrm{m}$ Earth Limb Emission under non-LTE conditions, Geophys. Res. Lett., 28, 1391-1394, 2001.

Mertens, C. J., Schmidlin, F. J., Goldberg, R. A., Remsberg, E. E., Pesnell, W. D., Russell III, J. M., Mlynczak, M. G., LopezPuertas, M., Wintersteiner, P. P., Picard, R. H., Winick, J. R., and Gordley, L. L.: SABER observations of mesospheric temperature and comparisons with falling sphere measurements taken during the year 2002 summer MaCWAVE campaign, Geophys. Res. Lett, 31, L03105, doi:10.1029/2003GL018605, 2004.

Mohanakumar, K.: Temperature variability over the tropical middle atmosphere, Ann. Geophys., 12, 448-456, doi:10.1007/s00585994-0448-y, 1994.

Narayana Rao, D., Kishore, P., Krishna Reddy, K., Hareesh, M., Narayana Rao, T., and Bhaskara Rao, S. V.: Application of Quality control algorithms to the Indian MST Radar wind data and comparison with rawinsonde wind data, Ind J. Rado. Phys, 27, 264-273, 1998.

Nee, J. B., Thulasiraman, S., Chen, W. N., VenkatRatnam, M., and Narayana Rao, D.: Middle atmosphere temperature structure over two tropical locations, Chung Li $(25 \mathrm{~N}, 121 \mathrm{E})$ and Gadanki (13.5N, 79.2E), J. Atmos. So. Terr. Phys., 64, 1311-1319, 2002.

Neter, J., Wasserman, W., Kunter, M. H.: Applied Linear Statitsical Models, edited by: Irwin, R. D., Homewood, Illinois, 1127 pp., 1985 .

Newchurch M. J., Bishop, L., Cunnold D., Flynn, L. E., Godin, S., Frith, S. H., Hood, L., Miller, A. J., Oltmans, S., Randel, W., Reinsel, G., Stolarski, R., Wang, R., Yang, E.-S., and Zawodny, J. M.: Upper-stratospheric ozone trends 1979-1998, J. Geophys. Res., 105, 14625-14636, doi:10.1029/2000JD900037, 2000.

Parameswaran, K., Sasi, M. N., Geetha Ramkumar., Nair, P. R., Deepa, V., Krishna Murthy, B. V., Prabhakaran Nayar, S. R., Revathy, K., Mrudula, G., Satheesan, K., Bhavanikumar, Y., Sivakumar, V., Raghunath, K., Rajendraprasad, T., and Krishnaiah, M.: Altitude profiles of temperature from 4 to $80 \mathrm{~km}$ over the tropics from MST radar and lidar, J. Atmos. Sol. Terr. Phys., 62, 13271337, 2000.

Raju, U. J. P., Keckhut, P., Courcoux, Y., Marchand, M., Bekki, S., Morel, B., Bencherif, H., and Hauchecorne, A.: Nocturnal temperature changes over tropics during CAWSES-III campaign: Comparisons with numerical models and satellite data, J. Atmos. Solar Terr. Phys., 72, 1171-1179, 2010.

Ramaswamy V., Chanin, M. -L., Angell, J., Barnett, D., Gaffen, D., Gelman, M., Keckhut, P., Koshelkov, Y., Labitzke, K., Lin, J.-J. R., O’Neill, A., Nash, J., Randel, W., Rood, R., Shine, K., Shiotani, M., and Swinbank, R.: Stratospheric temperature trends: Observations and model simulations, Rev. Geophys., 39, 71-122, 2001.

Randel, W. J. and Cobb, J. B.: Coherent variations of monthly mean total ozone and lower stratospheric temperature, J. Geophys. Res., 99, 5433-5477, 1994.

Randel, W. J. and Wu, F.: Biases in stratospheric and tropospheric temperature trends derived from historical radiosonde data, J. Climate, 19, 2094-2104, 2006.

Randel, W. J., Russell III, J., and Waters, J.: Space-time patterns of trends in stratospheric constituents derived from UARS measurements, J. Geophys Res., 104, 3711-3727, 1999.

Randel, W. J., Wu, F., Oltmans, S. J., Rosenlof, K., and Nedoluha, G.: Interannual changes of stratospheric water vapor and correlations with tropical tropopause temperature, J. Atmos. Sci., 61, 2133-2148, 2004.

Randel, W. J., Shine, K. P., Austin, J., Barnett, J., Claud, C., Gillett, N. P., Keckhut, P., Langematz, U., Lin, R., Long, C., Mears, C., Miller, A., Nash, J., Seidel, D. J., Thompson, D. W. J., Wu, F., and Yoden, S.: An update of observed stratospheric temperature trends, J. Geophys Res. 114, D02107, doi:10.1029/2008JD010421, 2009. 
Ratnam, M. V., Narayana Rao, D., Krishnaiah, M., Bhavani Kumar, Y., Siva Kumar, V., and Rao, P. B.: Coordinated MST radar and lidar observations for the study of mesospheric structures over a tropical station, J. Atmos. Sol. Terr. Phys., 64, 349-358, 2002.

Rees, D., Barnett, J. J., and Labitzke, K.: COSPAR International reference atmosphere 1986 Part II: Middle atmospheric models, COSPAR, Pergamon Press, New York, 1990.

Reid, G. C.: Seasonal and interannual temperature variations in the tropical stratosphere, J. Geophys. Res., 99, 18923-18932, 1994.

Remsberg, E.: On the observed changes in upper stratospheric and mesospheric temperatures from UARS HALOE, Ann. Geophys., 26, 1287-1297, doi:10.5194/angeo-26-1287-2008, 2008.

Remsberg, E.: Trends and solar cycle effects in temperature versus altitude from the Halogen Occultation Experiment for the mesosphere and upper stratosphere, J. Geophys. Res., 114, D12303, doi:10.1029/2009JD011897, 2009.

Remsberg E. E. and Deaver, L. E.: Interannual solar cycle, and trend terms in middle atmospheric temperature time series from HALOE, J. Geophys. Res., 110, D06106, doi:10.1029/2004JD004905, 2005.

Remsberg, E. E., Bhatt, P. P., and Deaver, L. E.: Seasonal and longer-term variations in middle atmosphere temperature from HALOE on UARS, J. Geophys. Res., 107 4411, doi:10.1029/2001JD001366, 2002.

Remsberg, E., Lingenfelser, G., Harvey, V. L., Grose, W., Russell III, J., Mlynczak, M., Gordley, L., and Marshall, B. T.: On the verification of the quality of SABER temperature, geopotential height, and wind fields by comparison with Met Office assimilated analyses, J. Geophys. Res., 108, 4628, doi:10.1029/2003JD003720, 2003.

Russell III, J. M., Gordley, L. L., Park, J. H., Drayson, S. R., Hesketh, W. D., Cicerone, R. J., Tuck, A. F., Frederick, J. E., Harries, J. E., and Crytzen, P. J.: Halogen occultation experiment, J. Geophys. Res., 98, 10777-10797, 1993.

Seidel, D. J., Ross, J. R., and Angell, J. K.: Climatological characteristics of the tropical tropopause as revealed by radiosondes, $\mathrm{J}$. Geophys. Res., 106, 7857-7878, 2001.
Shine, K. P., Bourqui, M. S., Forster, P. M.de F., Hare, S. H. E., Langematz, U., Braesicke, P., Grewe, V., Ponater, M., Schnadt, C., Smith, C. A., Haigh, J. D., Austin, J., Butchart, N., Shindell, D. T., Randel, W. J., Nagashima, T., Portmann, R. W., Solomon, S., Seidel, D. J., Lanzante, J., Klein, S., Ramawamy, V., and Schwarzkope, M. D.: A comparison of model-predicted trends in stratospheric temperatures, Q. J. R. Meterol. Soc., 129, 15651588, doi:10.1256/qj.02.186, 2003.

Singh, U. N., Keckhut, P., McGee, T. J., Gross, M. R., Hauchecorne, A., Fishbein, E. F., Waters, J. E., Gille, J. C., Roche, R. E., and Russell III, R. M.: Stratospheric temperature measurements by two collocated NDSC lidars during UARS validation campaign, J. Geophys. Res., 101, 10287-10297, 1996.

Sivakumar, V., Rao, P. B., and Krishnaiah, M.: Lidar measurements of stratosphere-mesosphere thermal structure at a low latitude: Comparison with satellite data and models, J. Geophy. Res., 108, 4342, doi:10.1029/2002JD003029, 2003.

Sivakumar, V., Vishnu Prasanth, P., Kishore, P., Bencherif, H., and Keckhut, P.: Rayleigh LIDAR and satellite (HALOE, SABER, CHAMP and COSMIC) measurements of stratospheremesosphere temperature over a southern sub-tropical site, Reunion $\left(20.8^{\circ} \mathrm{S} ; 55.5^{\circ} \mathrm{E}\right)$ : climatology and comparison study, Ann. Geophys., 29, 649-662, doi:10.5194/angeo-29-649-2011, 2011.

Sridharan, S., Vishnu Prasanth, P., and Bhavani Kumar, Y.: A report on long-term trends and variabilities in middle atmospheric temperature over Gadanki (13.5N, 79.2E), J. Atmos. Sol. Terr. Phys., 71, 1463-1470, 2009.

World Meteorological Organization (WMO), Scientific Assessment of Ozone Depletion: 1998, Rep. 44, Global Ozone Research and Monitoring Project, Report no. 44, Geneva, 1999.

Zhen-Shan, L. and Xian, S.: Multi-scale analysis of global temperature changes and trend of a drop in temperature in the next 20 years, Meteorol. Atmos. Phys., 95, 115-121, 2007. 